\title{
HIV-1 Fusion Is Blocked through Binding of GB Virus C E2D Peptides to the HIV-1 gp41 Disulfide Loop
}

\author{
Kristin Eissmann ${ }^{1}$, Sebastian Mueller ${ }^{1}$, Heinrich Sticht ${ }^{2}$, Susan Jung ${ }^{1}$, Peng Zou ${ }^{3}$, Shibo Jiang ${ }^{3,4}$, \\ Andrea Gross ${ }^{5}$, Jutta Eichler ${ }^{5}$, Bernhard Fleckenstein ${ }^{1}$, Heide Reil ${ }^{1 *}$
}

$\mathbf{1}$ Institute of Virology, Friedrich-Alexander-Universität Erlangen-Nürnberg, Erlangen, Germany, 2 Bioinformatics, Institute of Biochemistry, Friedrich-Alexander-Universität Erlangen-Nürnberg, Erlangen, Germany, 3 Lindsley F. Kimball Research Institute, New York Blood Center, New York, New York, United States of America, 4 Key Laboratory of Medical Molecular Virology of Ministries of Education and Health, Shanghai Medical College, Institute of Medical Microbiology, Fudan University, Shanghai, China, 5 Medicinal Chemistry, Friedrich-Alexander-Universität Erlangen-Nürnberg, Erlangen, Germany

\begin{abstract}
A strategy for antiviral drug discovery is the elucidation and imitation of viral interference mechanisms. HIV-1 patients benefit from a coinfection with GB Virus C (GBV-C), since HIV-positive individuals with long-term GBV-C viraemia show better survival rates than HIV-1 patients without persisting GBV-C. A direct influence of GBV-C on HIV-1 replication has been shown in coinfection experiments. GBV-C is a human non-pathogenic member of the flaviviridae family that can replicate in $\mathrm{T}$ and $\mathrm{B}$ cells. Therefore, GBV-C shares partly the same ecological niche with HIV-1. In earlier work we have demonstrated that recombinant glycoprotein E2 of GBV-C and peptides derived from the E2 N-terminus interfere with HIV entry. In this study we investigated the underlying mechanism. Performing a virus-cell fusion assay and temperature-arrested HIVinfection kinetics, we provide evidence that the HIV-inhibitory E2 peptides interfere with late HIV-1 entry steps after the engagement of gp120 with CD4 receptor and coreceptor. Binding and competition experiments revealed that the $\mathrm{N}$ terminal E2 peptides bind to the disulfide loop region of HIV-1 transmembrane protein gp41. In conjunction with computational analyses, we identified sequence similarities between the N-termini of GBV-C E2 and the HIV-1 glycoprotein gp120. This similarity appears to enable the GBV-C E2 N-terminus to interact with the HIV-1 gp41 disulfide loop, a crucial domain involved in the gp120-gp41 interface. Furthermore, the results of the present study provide initial proof of concept that peptides targeted to the gp41 disulfide loop are able to inhibit HIV fusion and should inspire the development of this new class of HIV-1 entry inhibitors.
\end{abstract}

Citation: Eissmann K, Mueller S, Sticht H, Jung S, Zou P, et al. (2013) HIV-1 Fusion Is Blocked through Binding of GB Virus C E2D Peptides to the HIV-1 gp41 Disulfide Loop. PLoS ONE 8(1): e54452. doi:10.1371/journal.pone.0054452

Editor: Welkin E. Johnson, Boston College, United States of America

Received September 29, 2012; Accepted December 11, 2012; Published January 22, 2013

Copyright: (c) 2013 Eissmann et al. This is an open-access article distributed under the terms of the Creative Commons Attribution License, which permits unrestricted use, distribution, and reproduction in any medium, provided the original author and source are credited.

Funding: This work was supported by grants of the Akademie der Wissenschaften und Literatur zu Mainz, project 21.223 (HR), the Interdisziplinäres Zentrum für Klinische Forschung (IZKF): Teilprojekt B16 (HR), Deutsche Forschungsgemeinschaft: GRK1071, projects A5 (KE), A7 (AG), Bayerisches Staatsministerium für Wissenschaft, Forschung und Kunst: "Förderung der Chancengleichheit für Frauen in Forschung und Lehre" (KE, SJ), the Sonderforschungsbereich 796: project A2 (HS), A5 (JE), and the National Natural Science Foundation of China (NSFC-81173098) to ShJ. The funders had no role in study design, data collection and analysis, decision to publish, or preparation of the manuscript.

Competing Interests: The authors have declared that no competing interests exist.

* E-mail: heide.reil@viro.med.uni-erlangen.de

\section{Introduction}

$\mathrm{GB}$ virus $\mathrm{C}(\mathrm{GBV}-\mathrm{C})$ is a common human virus that can be transmitted sexually, parenterally and vertically from mother to child [1,2]. Infection of immunocompetent individuals usually leads to clearance of GBV-C viraemia within the first years; however, GBV-C can cause persistent infection in approximately $25 \%$ of cases [3]. As a member of the flaviviridae family, for which a fourth genus, termed Pegivirus, was recently proposed, it is related to the hepatitis $\mathrm{G}$ virus (HCV) [4]. However, acute and persistent infection with GBV-C does not appear to be associated with hepatitis or any other diseases in humans (reviewed in $[5,6])$. The GBV-C genome is a positive-sense, single-stranded RNA (9.4 kb) that contains one long open reading frame (ORF) [7-9]. The polyprotein is post-translationally processed by cellular and viral proteases into the structural proteins such as E1 and E2, as well as the nonstructural proteins NS2, NS3, NS4A/B and NS5A/B [10]. In most industrialized countries $1 \%$ to $5 \%$ of healthy individuals are viraemic for GBV-C and $10 \%$ to $15 \%$ have developed anti-E2 antibodies as evidence of past GBV-C infection [11]. In contrast to $\mathrm{HCV}$, in the majority of GBV-C infected individuals, the occurrence of anti-E2 antibodies is associated with clearance of the virus [12]. However, GBV-C elimination has been documented without the appearance of anti-E2 antibodies, indicating that a diagnosis based merely on the detection of anti-E2 antibodies in serum might lead to an underestimation of prevalence of prior infection. Based on the common transmission routes, the prevalence of GBV-C in $\mathrm{HCV}$ and $\mathrm{HIV}-1$-positive individuals is much higher than in the general population. GBV-C RNA prevalence rates range from $20 \%$ to $30 \%$ in HCV coinfected individuals and from $15 \%$ to $40 \%$ in HIV-1 patients (reviewed in [3]). Several, but not all, epidemiological studies and a metaanalysis have reported that GBV-C viraemia has a beneficial effect on the course of HIV-1 disease progression and survival [13-20]. Furthermore, mother-to-child transmission of GBV-C reduces the vertical transmission of HIV-1 from GBV-C/HIV-1 coinfected mothers [21], and recently it was reported that accidental GBV-C acquisition via transfusion is associated with a significant reduction 
in mortality in HIV-infected individuals [22]. GBV-C is a lymphotropic virus that replicates primarily in $\mathrm{B}$ and $\mathrm{T}$ cells [23]. Therefore, it occupies, at least in part, the same ecological niche as HIV-1. Several effects have been proposed to explain the interference with HIV-1, including induction of chemokines, CD4 receptor and coreceptor modulation, prevention of Th2 cytokine profile, reduction of $\mathrm{T}$ cell activation, as well as downmodulation of FAS-mediated apoptosis in GBV-C coinfected individuals [2431]. Cell culture experiments revealed a direct influence on HIV-1 replication by at least two GBV-C proteins, i.e., the nonstructural protein NS5A and the E2 envelope protein [31,32]. Whereas NS5A leads to decreased HIV-1 receptor expression and stabilization of the Thl profile, the E2 protein prevents HIV-1 entry by a mechanism as yet unknown [31,33-35]. Using synthetic peptides presenting different regions of E2, we recently demonstrated that this interference with HIV-1 entry can be ascribed to the N-terminal part of the GBV-C E2 protein ranging from residue 29 to 72 (according to GenBank accession no. AF121950) [33]. Two overlapping 20 mer peptides (P4-7 and P6-2) presenting amino acids 37 to 56 (WDRGNVTLLCDCPNGPWVWV) and 45 to 64 (LGDGPNGPWVWVPAFGQAVG), respectively, of the GBV-C E2 protein, were shown to be most potent with $\mathrm{IC}_{50} \mathrm{~S}$ between 2 and $0.2 \mu \mathrm{M}$ in a TZM-bl-based HIV-1 replication assay.

Cell entry of HIV-1 is mediated by noncovalently associated trimers of gp120 and gp4l subunits assembled into functional spikes on the surface of virions. The noncovalent association between the two subunits appears to be maintained by interaction of the N-and C-termini of gp120 with the disulfide loop region of gp41 and parts of the flanking $\mathrm{N}$ - and C-terminal heptad repeat regions (NHR and CHR) (reviewed in [36]). The primary receptor for gp120 is CD4, which is expressed on the surface of monocytes, macrophages, and on subsets of dendritic and T cells [37]. Upon engagement of CD4, gp120 undergoes a conformational shift, enabling binding to the chemokine coreceptors CXCR4 or CCR5, respectively $[38,39]$. This interaction is thought to induce additional conformational changes in the envelope trimer that result in exposure of the hydrophobic fusion peptide of gp41 and its insertion into the host cell membrane. Subsequently, the NHR and CHR regions of gp 41 fold back and interact with each other, in order to form a six-helix bundle $(6-\mathrm{HB})$, that promotes the convergence of the viral and cellular membrane and the formation of the membrane pore (reviewed in [40]).

In this study, we aimed to elucidate the mechanism of action by which GBV-C E2 20 mer peptides P4-7 and 6-2, representing the E2 residues from 37 to 64, inhibit HIV-1 entry. We demonstrate that E2 peptides act late after CD4 and coreceptor engagement via binding the gp41 disulfide loop region, a new promising target for HIV-1 entry inhibition.

\section{Materials and Methods}

\section{Peptides}

$\mathrm{N}$-acetylated or fluorescein-conjugated peptides derived from the GBV-C glycoprotein E2 (P4-7, P4-7s, P6-2, P6-2s, P9, and $\mathrm{P} 28)$ were obtained from EMC Microcollections (Tübingen, Germany). All other peptides (listed in Table S1) were synthesized by a standard solid-phase FMOC method using a peptide synthesizer. The N- and C-termini of N36 and C34, as well as the gp120 N-terminus peptides, were acetylated and amidated, respectively. The gp41 disulfide peptides (Loop36ox and Loop36s) were $\mathrm{N}$-terminally biotinylated for site-selective attachment to streptavidin-coated assay plates. Loop36o $\times$ was cyclized by formation of a disulfide bridge between the two cysteine residues through air oxidation at $\mathrm{pH}$ 8. The peptides were purified to homogeneity ( $>95 \%$ purity) by high-performance liquid chromatography and verified by laser desorption mass spectrometry (PerSeptive Biosystems, Framingham, MA) and by ESI mass spectrometry, respectively. Peptide stocks were dissolved in $75 \%$ DMSO $/ \mathrm{H}_{2} \mathrm{O}$ and diluted for experiments in respective buffers or medium.

\section{Virus Stocks}

HIV-1 virions containing the BlaM-Vpr chimera were produced as previously described [33]. Briefly, 293T cells were cotransfected with pNL4-3 proviral DNA, pCMV-BlaM-Vpr, and pAdVAntage vectors. After 2 days of cultivation, the viruscontaining supernatant was centrifuged for $10 \mathrm{~min}$ at $300 \times \mathrm{g}$ to remove cellular debris. The HIV-1 virion-containing supernatant was overlaid onto a $20 \%$ sucrose cushion and ultracentrifuged at $35000 \times \mathrm{g}$ at $4^{\circ} \mathrm{C}$ for $90 \mathrm{~min}$. The resulting pellet was resuspended in medium and aliquots were frozen at $-80^{\circ} \mathrm{C}$ until usage.

\section{HIV-1 Receptor Expression}

PHA/IL-2-stimulated PBMC or TZM-bl cells were incubated with E2 peptides $(25 \mu \mathrm{M})$, phorbol 12-myristate 13-acetate (PMA; $40 \mathrm{ng} / \mathrm{ml}), \operatorname{SDF}-1 \alpha(1 \mu \mathrm{g} / \mathrm{ml})$ or RANTES $(50 \mathrm{nM})$ for $6 \mathrm{hr}$. CD4, CXCR4 and CCR5 surface expression was analyzed by using standard FACS staining protocols. Cells were washed with PBS and incubated for $30 \mathrm{~min}$ at $4^{\circ} \mathrm{C}$ with PE-labeled antibodies (CD4 clone SK3, CXCR4 clone 12G5, and CCR5 clone 2D7, BD Biosciences, Germany). Subsequently, washed cells were resuspended in PBS and analyzed with a FACSCalibur ${ }^{\mathrm{TM}}$ flow cytometer (BD Biosciences, Germany).

\section{HIV-1 Virion-based Fusion Assay}

The virion-based fusion assay was performed essentially as described elsewhere [41]. Briefly, $5 \times 10^{4}$ TZM-bl cells were infected with sucrose-purified HIV-1 NL4-3 virions containing BlaM-Vpr (5 ng p24-Gag per approach). Under temperaturearrested state (TAS) conditions, binding of the HI virions to target cells was allowed at low temperature via spinning inoculation, for which virions were added to cells and centrifuged at $2095 \times \mathrm{g}, 4^{\circ} \mathrm{C}$ for $30 \mathrm{~min}$. To remove unbound virus particles, cells were washed with cold medium and incubated with $20 \mu \mathrm{M}$ of each E2 peptide or respective controls (AMD-3100 [10 $\mu \mathrm{M}], 2 \mathrm{~F} 5[0.5 \mu \mathrm{g} / \mathrm{ml}], \mathrm{b} 12$ $[0.3 \mu \mathrm{g} / \mathrm{ml}]$, and $\mathrm{B} 4[0.3 \mu \mathrm{g} / \mathrm{ml}])$ at $23^{\circ} \mathrm{C}$ for $1 \mathrm{~h}$. Virus-cell fusion was initiated by a temperature shift to $37^{\circ} \mathrm{C}$ for a total of $2 \mathrm{hr}$. Under standard conditions, E2 peptides, or defined control agents, were added to cell culture shortly before HIV-1 inoculation, and cells were incubated at $37^{\circ} \mathrm{C}$ for $2 \mathrm{hr}$. Subsequently, cells were washed with HBSS, loaded with the CCF2-AM substrate, as described by the manufacturer (Invitrogen, Germany), and incubated overnight at $20^{\circ} \mathrm{C}$. BlaM activity was quantified using a fluorescence plate reader. The extent of viruscell fusion was determined from the ratio of blue $(460 \mathrm{~nm})$ and green $(510 \mathrm{~nm})$ emission upon exciting the cells at $405 \mathrm{~nm}$.

\section{HIV-1 gp120 Binding to CD4, CCR5, and CXCR4}

HIV-1 gp120 binding studies using flow cytometry were performed as previously described [42]. Briefly, supernatants containing soluble $\mathrm{F}_{\mathrm{C}}$-gp $120_{\text {JRCSF }}$ fusion protein or the $\mathrm{FC}_{\mathrm{C}}$ control protein were obtained from transiently transfected 293T cells. For binding studies, 293T cells were transiently transfected with pCD4 expression plasmid or an empty plasmid as control, and preincubated with $40 \mu \mathrm{M}$ of the $\mathrm{E} 2$ peptides, $1 \mu \mathrm{M}$ sCD4, $3 \mu \mathrm{g} / \mathrm{ml}$ VRC01, or $10 \mu \mathrm{M}$ of the CCR5 inhibitor TAK-779. 


\section{A. PBMC}
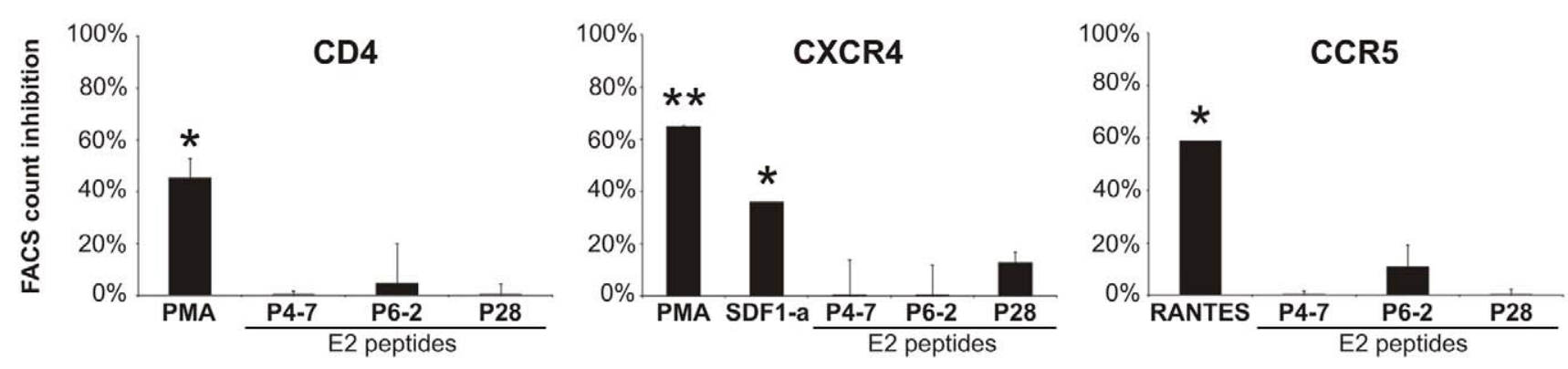

\section{B. TZM-bl}
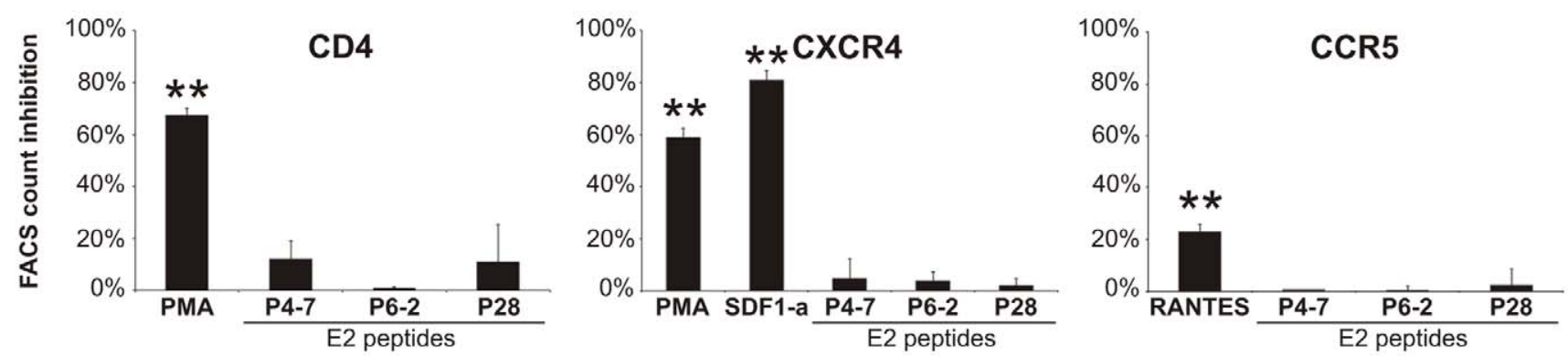

Figure 1. E2-derived peptides do not alter CD4 or coreceptor surface expression. CD4, CXCR4 and CCR5 expression on PBMC ( $A$ ) and TZMbl cells (B) after preincubation with E2 peptides were determined by flow cytometry analysis. Positive controls like PMA (phorbol 12-myristate 13acetate) lead to down-regulation of CD4, SDF-1 $\alpha$ (CXCR4-ligand) and RANTES (CCR5-ligand) to down-regulation of the respective coreceptors, while E2 peptides P4-7 and P6-2 including the negative control P28 had no relevant effect on HIV-1 receptor presentation. Percentages illustrate the ratioto-cell-negative (RTCN) values that were calculated from the percentage of positive cells and the fluorescence intensity of peptide-incubated cells compared to mock-incubated cells. Columns show average values \pm SD of two independent experiments each performed in triplicate. *: $p<0.05 ;{ }^{* *}$ : $p<0.01$ (mock- vs. inhibitor-incubated cells).

doi:10.1371/journal.pone.0054452.g001

Similar amounts of soluble Fc-gp 120 or Fc control, were added for $45 \mathrm{~min}$ on ice, and cells were washed and stained with anti-human IgG, FITC-conjugated secondary antibody (Dako, Germany) for $30 \mathrm{~min}$ at $4^{\circ} \mathrm{C}$. Subsequently, washed cells were resuspended in PBS and analyzed with a FACSCalibur ${ }^{\mathrm{TM}}$ flow cytometer. Data were collected with BD CellQuest ${ }^{\mathrm{TM}}$ and analyzed with FCS Express V3. In parallel, GD4 and CCR5 expression was determined by staining with the antibody clones SK3 and 2D7, respectively (BD Biosciences, Germany).

HIV-1 gp120 binding studies by immunoblotting were performed as previously described [43]. Briefly, 293T cells were transiently transfected with either pCD4 or pCCR5 expression plasmids. Verification of expression was performed 2 days after transfection via flow cytometry. After 2 days of cultivation, the cells were resuspended in binding buffer $(50 \mathrm{mM}$ HEPES, $5 \mathrm{mM} \mathrm{MgCl}_{2}, 1 \mathrm{mM} \mathrm{CaCl} 2,5 \%$ BSA, $\left.0.1 \mathrm{mM} \mathrm{NaN}_{3}, \mathrm{pH} 7.5\right)$. In a $50 \mu \mathrm{l}$ binding assay, either $40 \mu \mathrm{M}$ TAK-779 or Maraviroc, $0.8 \mu \mathrm{M}$ sCD4, $40 \mu \mathrm{g} / \mathrm{ml}$ VRC01, $160 \mu \mathrm{g} / \mathrm{ml}$ 447-52D, $200 \mu \mathrm{g}$ / ml F425B4e8 (all: NIH AIDS Research and Reference Reagent Program), $40 \mu \mathrm{g} / \mathrm{ml} 5 \mathrm{~F} 3$ (Polymun Scientific), $0.6 \mu \mathrm{M} \mathrm{E} 2_{340}-\mathrm{Fc}$ or Fc control, $0.2 \mathrm{mM} \mathrm{P4-7,} \mathrm{P6-2} \mathrm{or} \mathrm{P28} \mathrm{and} \mathrm{additionally} 10 \mu \mathrm{g} / \mathrm{ml}$ HIV-1 ${ }_{\mathrm{BaL}}$ or HIV-1 ${ }_{\text {IIIB }}$ gp1 20 protein (NIH AIDS Research and Reference Reagent Program) were added. After incubation for $1 \mathrm{~h}$ at $37^{\circ} \mathrm{C}$, cells were washed with cold PBS and lysed in Triton X100 and Tween-20 containing buffer. Lysates were separated by a $5 \%$ SDS-PAGE and verified with monoclonal gp120 antibody F425 B4al (NIH AIDS Research and Reference Reagent Program) or with sheep $\alpha$-HIV-1-gp120 (Aalto Bio Reagents
Ltd.) in Western Blot analyses. HIV-1 gp120 (5 ng) was used as a standard. Detection was achieved with HRP-conjugated antihuman antibody and chemiluminescence reagents.

\section{HIV-1 gp160 Binding}

293T cells were transiently transfected with an HIV-1 Env expression vector, coding for the CXCR4-tropic NL4-3 gp160 precursor (X4env) for surface expression of gp120-gp41 Env trimers or empty plasmid as control. After 2 days of cultivation, cells were incubated with $1 \mu \mathrm{g}$ sCD4 and $1 \mu \mathrm{M}$ FITC-conjugated E2 peptides for $1 \mathrm{~h}$ at $37^{\circ} \mathrm{C}$ respectively. Subsequently, cells were washed, resuspended in PBS, and analyzed by flow cytometry using a BD ${ }^{\text {TM }}$ LSR II flow cytometer (Becton Dickinson Biosciences, Germany). Flow cytometer data were collected with BD FACSDiva ${ }^{\mathrm{TM}}$ and analyzed with FCS Express V3. In parallel, gp160 expression was determined by staining with HIV-1 gp120 mAbs (2G12 and 17b) and an anti-human IgG-FITC pAb (Dako, Germany).

\section{ELISA Procedures}

Flat-bottom, 96-well Microtest ELISA plates (Sarstedt, Germany) were coated overnight at $4^{\circ} \mathrm{C}$ with recombinant HIV-1 gp120 $(0.5 \mu \mathrm{g} / \mathrm{ml})$, gp41 $(0.22 \mu \mathrm{g} / \mathrm{ml})$ proteins, or with streptavidin $(4 \mu \mathrm{g} / \mathrm{ml})$ in coating buffer $\left(0.1 \mathrm{M} \mathrm{NaHCO}_{3}, 0.1 \mathrm{M} \mathrm{Na}_{2} \mathrm{CO}_{3}\right.$, $\mathrm{pH}$ 9.87). Nonspecific binding was blocked (blocking buffer: $1 \%$ BSA, $0.1 \%$ Tween-20 in phosphate buffer, $\mathrm{pH} 7.2$ ) for $1 \mathrm{~h}$ at room temperature, followed by washing steps (wash buffer: $0.1 \%$ Tween in phosphate buffer, $\mathrm{pH}$ 7.2). Streptavidin-coated plates 


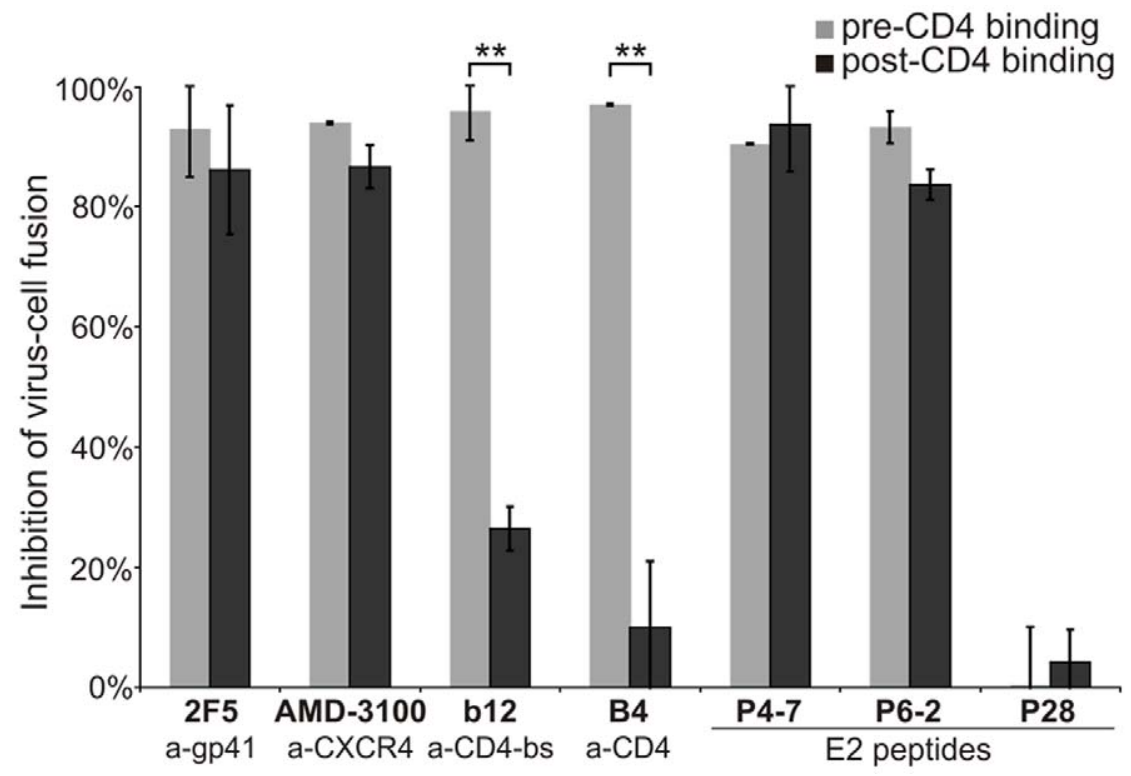

Figure 2. E2-derived peptides inhibit the HIV-1 fusion process. The HIV-inhibitory activity of known HIV-1 entry inhibitors or respective E2 peptides was determined using a virus-cell fusion assay under standard (respective inhibitors were added simultaneously to HIV NL4-3 BlaM-Vpr inoculum: pre-CD4 binding) or under TAS (temperature-arrested state) conditions (respective inhibitors were added at low temperature of $23^{\circ} \mathrm{C}$ for $1 \mathrm{~h}$ after spin-inoculation $\left[4^{\circ} \mathrm{C}\right]$ and removal of unbound HIV-1 particles: post-CD4 binding). Subsequently, HIV-1 fusion was enabled via a temperature shift to $37^{\circ} \mathrm{C}$. Antibodies b12 (anti [a]-CD4-binding site [bs]) and B4 (a-CD4) are early inhibitors interfering with CD4 engagement, whereas 2F5 (MPER antibody) and AMD-3100 (CXCR4 antagonist) act after CD4 binding. The E2 peptide P28 served as a negative control. The extent of virus-cell fusion was determined from the ratio of blue $(460 \mathrm{~nm})$ and green $(510 \mathrm{~nm})$ emission upon exciting the cells at $405 \mathrm{~nm}$ using a fluorescence plate reader. Percentages were calculated in relation to mock-treated cells. Columns show average values $\pm S D$ of five independent experiments each performed in triplicate. ${ }^{* *}: p<0.01$.

doi:10.1371/journal.pone.0054452.g002

were then incubated with gp41 disulfide loop peptides (Loop36ox or Loop36s; $2.5 \mu \mathrm{M})$. All plates were then incubated with recombinant $\mathrm{E} 2340-\mathrm{Fc}_{\mathrm{c}}$ or $\mathrm{Fc}$ protein in serial dilutions in sample buffer (phosphate buffer, $\mathrm{pH}$ 7.2) for $3 \mathrm{hr}$ at room temperature. To perform the competitive ELISAs, the recombinant E2 $340-\mathrm{Fc}$ protein was adjusted at $5 \mu \mathrm{g} / \mathrm{ml}$ and the monoclonal gp41 antibodies (246-D, F240, T32, D50, 2F5, 4E10, Chessie 8 [all: NIH AIDS Research and Reference Reagent Program], and 5F3 [Polymun, Austria]) at $100 \mu \mathrm{M}$. After washing procedure, the plates were incubated for $1 \mathrm{~h}$ with polyclonal rabbit anti-human IgG peroxidase antibody (Dako, Germany) 1:6000 in sample buffer and washed. Plates were developed with TMB peroxidase substrate solution (KPL, USA), or with $\mathrm{OPD} / \mathrm{H}_{2} \mathrm{O}_{2}$ solution in the dark. Absorbances (ODs) were read at 450 or $492 \mathrm{~nm}$, respectively, using a multi-channel photometer (ELISA-Reader AxSYM, Abbott Laboratory, USA).

\section{Inhibition of 6-HB Formation}

Inhibitory activity of the peptides (P4-7, P6-2, and P28) on 6HB formation was measured by a modified ELISA-based method as previously described [44]. Briefly, 96-well polystyrene plates were coated with the 6-HB-specific monoclonal antibody, NC$1 \mathrm{IgG}$, (described by [45]) (2 $\mu \mathrm{g} / \mathrm{ml}$ in $0.1 \mathrm{M}$ Tris, $\mathrm{pH} 8.8$ ), and then blocked with $2 \%$ non-fat milk. N36 $(0.25 \mu \mathrm{M})$, the tested peptides and C34 as control were added at graded concentrations into the wells. After incubation for $30 \mathrm{~min}$ at $37^{\circ} \mathrm{C}$, C34-biotin $(0.25 \mu \mathrm{M})$ was added, followed by incubation for $45 \mathrm{~min}$ at $37^{\circ} \mathrm{C}$ and washing with wash buffer (PBS containing $0.05 \%$ Tween-20) six times. Streptavidin-labeled horseradish peroxidase (Invitrogen, Grand Island, NY) and the substrate 3,3',5,5' -tetramethylbenzidine (Sigma, St. Louis, MO) were added sequentially. Absorbance at $450 \mathrm{~nm}\left(\mathrm{OD}_{450}\right)$ was measured. The percent inhibition of 6-HB formation by the peptides was calculated as described before [46].

\section{Computational Methods}

Globular and disordered regions in E2 were identified using GlobPlot2.3 [47] with standard settings. Secondary structure prediction was performed using the consensus prediction method provided by the NPS@ server [48]. Structural homologs were identified with the bioinfo.pl meta prediction server [49], and modelling was performed with Modeller6.2 [50], using the crystal structure of a single-variable-domain antibody (PDB code: 2Z8W) as template [51]. Sequence comparison between different E2 proteins and between E2 and gp160 was performed with LALIGN (http://www.ch.embnet.org/software/LALIGN_form.html) using the local alignment option. The gp160 signal peptide comprising residues 1 to 30 was removed prior to the similarity searches because it is not present in the mature protein.

\section{Statistics}

All statistical analyses were performed using Wilcoxon rank-sum test (two-tailed).

\section{Results}

\section{GBV-C E2-derived Peptides do not Alter Cell Surface Presentation of HIV-1 Receptors}

It has been shown that the HIV-1 receptor/coreceptor density plays a critical role in the efficiency of HIV-1 fusion and infection [52]. Thus, we addressed the question of whether or not the two overlapping GBV-C E2 20 mer peptides P4-7 and P6-2 have an impact on the cell surface presentation of the HIV-1 receptors CD4 and CXCR4 or CCR5, respectively. The cell surface 
A

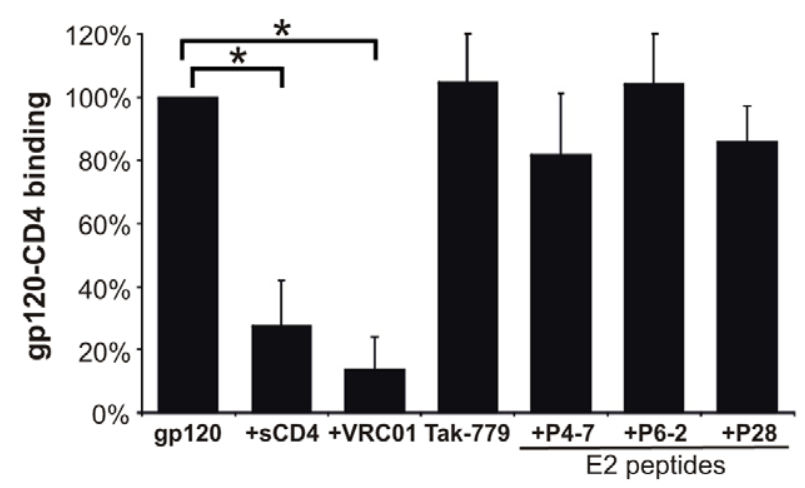

C

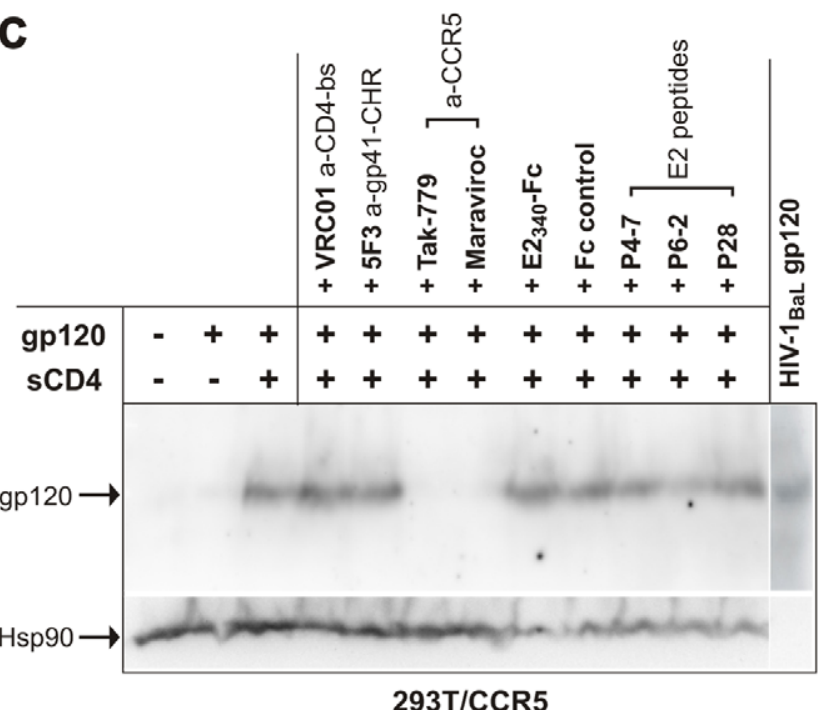

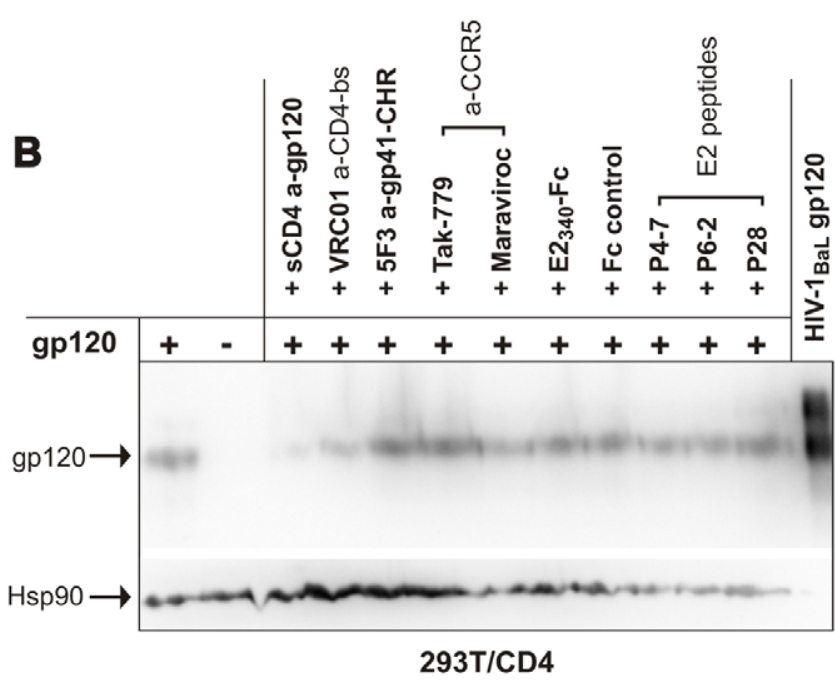

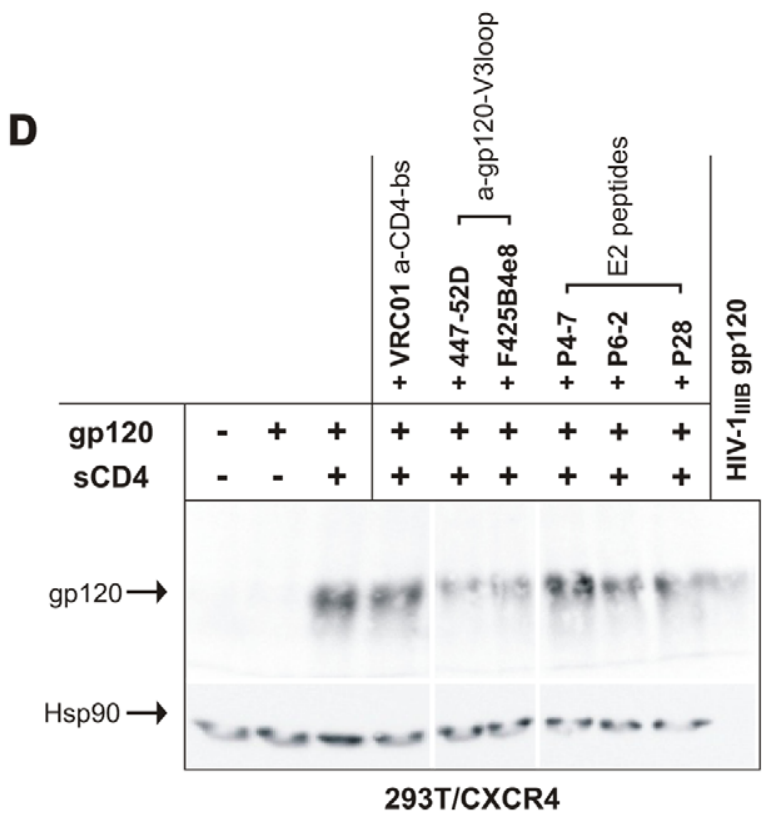

Figure 3. E2-derived peptides do not influence HIV-1 gp120 binding to CD4 and CCR5. (A) 293T cells expressing CD4 were preincubated with E2-derived peptides and specific controls that bind to gp120 (sCD4; VRC01, directed against CD4 binding site [bs]) or CCR5 (Tak-779). Subsequently, cells were incubated with soluble Fc-gp120 (HIV-1 JRCSF) and binding to CD4 was analyzed by flow cytometry using a FITC-conjugated anti-human IgG pAb. Binding to cells in the absence of inhibitor was set as $100 \%$. Columns show average values \pm SD of three independent experiments each performed in duplicate. ${ }^{*}: p<0.05$ In (B) and (C) 293T cells expressing CD4, CCR5, or CXCR4 were preincubated with E2-derived peptides, E2 ${ }_{340}-\mathrm{Fc}$ and Fc protein as well as specific controls that bind to gp120 (sCD4, VRC01, 447-52D, F425 B4e8), gp41 (5F3), or CCR5 (Tak-779, Maraviroc). Soluble HIV-1 gp120 was added to the CD4-, CCR5-, or CXCR4-expressing cells and binding was investigated by separating the cell lysates on SDS-PAGE and visualized by performing Western Blot analyses. No influence of E2 peptides or intact E2 protein on the binding efficiency between gp120 and CD4, CCR5, or CXCR4 respectively, was observed after normalization of band intensity with the gel loading control Hsp90.

doi:10.1371/journal.pone.0054452.g003

presentation of these receptors was quantified via flow cytometry after incubation of primary peripheral blood mononuclear cells (PBMCs) and of HeLa-derived HIV indicator cells expressing CD4, CGR5 and CXCR4, designated as TZM-bl cells, with the E2 peptides $\mathrm{P} 4-7$ and $\mathrm{P} 6-2$. The non-HIV-1-inhibitory peptide P28 derived from the C-terminal part of E2 (residue 271 to 290), served as a negative control [33]. As shown in Figure 1, both CD4 and coreceptor expression on PBMC or TZM-bl cells remained largely unaffected by E2 peptides, thereby eliminating a change in receptor density as a mode of action of the $\mathrm{E} 2$ peptides.
The Effect of GBV-C E2 Peptides Arises After gp120/CD4 and gp120/coreceptor engagement

To find out whether early or late steps of HIV-1 entry are affected by the E2 peptides, the E2 peptide activity was determined before and after gp120/CD4 engagement using the $\mathrm{Vpr}$ - $\beta$-lactamase (Vpr-BlaM) enzyme-based virus-cell fusion assay under standard (pre-CD4 binding) and temperature-arrested state (TAS; post-CD4 binding) conditions, respectively. Based on the temperature sensitivity of envelope-mediated membrane fusion, low temperature $\left(<28^{\circ} \mathrm{C}\right)$ during and after CD4/gp120 engage- 


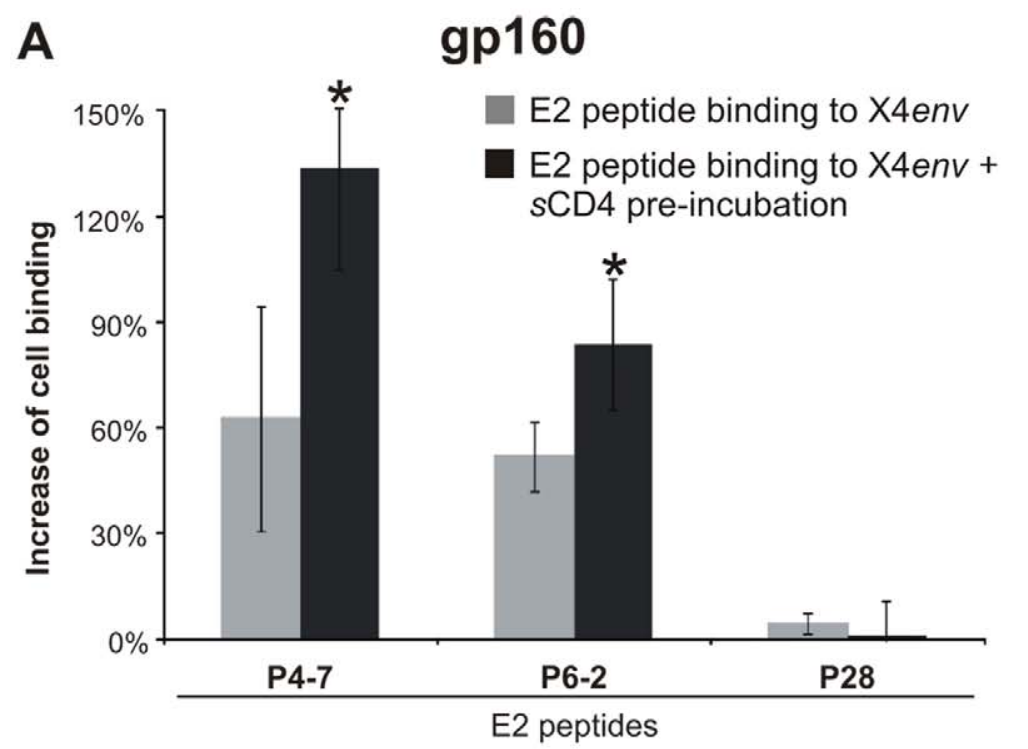

B
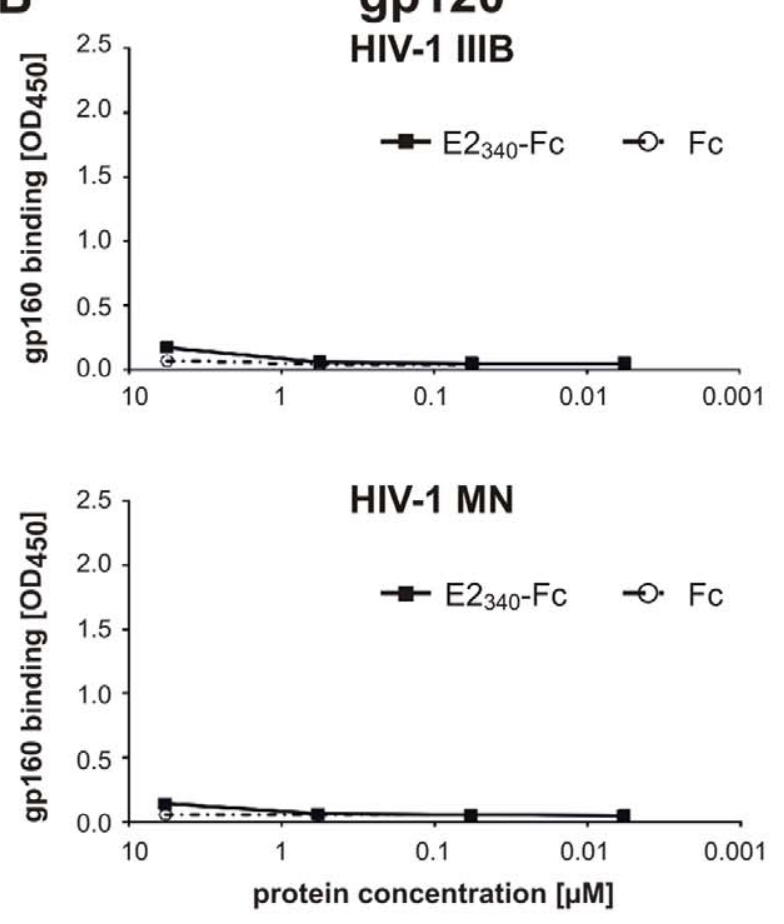

C

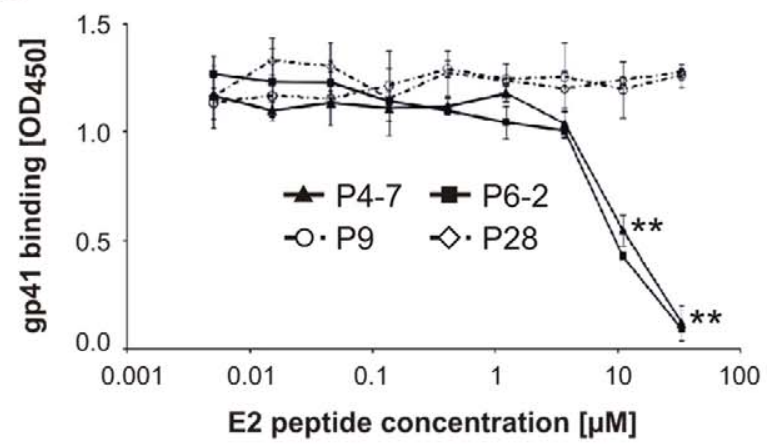

gp41
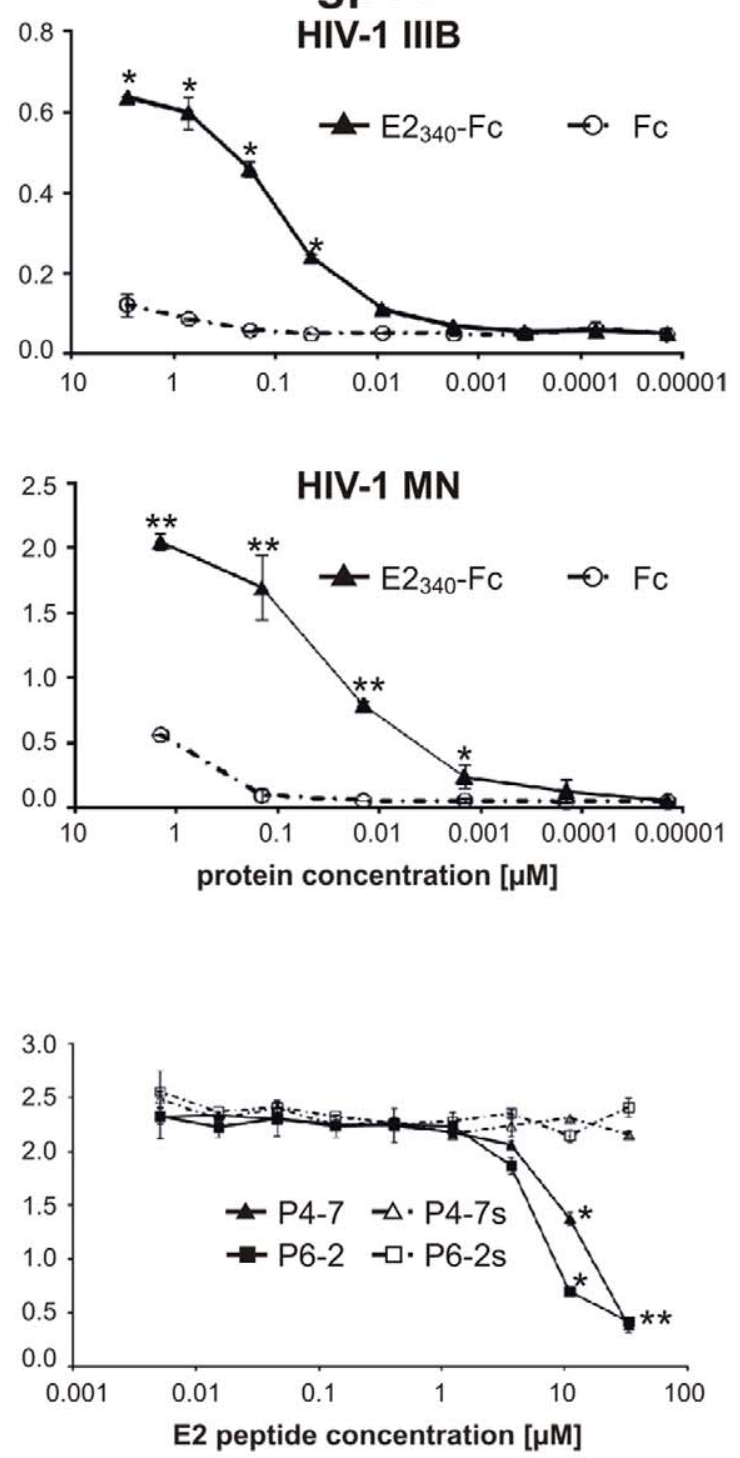
Figure 4. Recombinant E2 $\mathbf{3 4 0}_{\mathbf{4}}$-Fc protein and E2-derived peptides bind HIV-1 gp41. (A) 293T cells expressing NL4-3 envelope (X4env) or empty plasmid as control were incubated with SCD4 and FITC-conjugated E2 peptides, respectively. Peptide binding was analyzed by flow cytometry. Percentages illustrate the increase of cell binding to X4env-transfected cells. The increase is normalized to the background binding of E2 peptides to mock-transfected cells by calculating the RTCN value. Columns show average values \pm SD of three independent experiments each performed in duplicate. ${ }^{*} \mathrm{p}<0.05$ (vector- vs. X4env-transfected cells) (B) Binding of recombinant E2 340 -Fc protein and Fc protein as control to recombinant HIV-1 glycoproteins ( $\mathrm{gp} 120_{\mathrm{IIIB}}, \mathrm{gp} 120_{\mathrm{MN}}, \mathrm{gp} 41_{\mathrm{IIIB}}$, or $\mathrm{gp} 41_{\mathrm{MN}}$ ). (C) E2 peptides with increasing amounts were added to recombinant $\mathrm{E} 2_{340}-\mathrm{FC}$ protein (at constant concentration) and then transferred to immobilized recombinant gp $41_{\mathrm{MN}}$. All ELISA graphs show average values of three independent experiments each performed in duplicate. * $p<0.05 ;{ }^{* *}: p<0.01$ (E2 $340-\mathrm{Fc}, \mathrm{Fc}, \mathrm{P} 4-7$, or P6-2 vs. P28).

doi:10.1371/journal.pone.0054452.g004

ment leads to an arrest of the fusion process at an intermediate state and the blockade of coreceptor binding, 6 -HB formation, and final membrane fusion [53-55]. As shown in Figure 2, the effect of antibodies that interfere with the initial CD4/gp120 interaction (b12 and B4) was largely abrogated under TAS conditions. In contrast, P4-7 and P6-2 showed full activity under both conditions, comparable to known fusion inhibitors like AMD-3100 and the neutralizing MPER antibody 2F5 that act after CD4 engagement. Therefore, these data provide evidence that $\mathrm{P} 4-7$ and $\mathrm{P} 6-2$ implement their HIV-1 inhibitory activity post-CD4 binding of gp120.

To substantiate this conclusion, next we assessed the impact of E2 peptides on gp120 binding to CD4. Immunoblotting and flow cytometry data revealed that E2 peptides and the whole E2 ectodomain fused to the $\mathrm{Fc}$ domain of human $\operatorname{IgG}\left(\mathrm{E} 2_{340}-\mathrm{Fc}\right)$ that showed HIV-1 inhibitory activity in earlier studies [32] do not interfere with the interaction of recombinant gp120 with cellular expressed CD4 (Figure 3A, B). In a related approach, the effect of $\mathrm{E} 2$ peptides or intact $\mathrm{E} 2$ protein on the interaction between gp120 and the coreceptors CGR5 and CXCR4 expressed on cells was tested by immunoblotting. To ensure efficient binding of gp 120 to the coreceptors, soluble CD4 (sCD4) was added simultaneously. Use of CCR5-antagonists Maraviroc and TAK-779 or anti-gp120 coreceptor binding site (V3-loop) antibodies 447-52D or F425B4e8, respectively, as positive controls revealed a clear reduction in the gp120/CCR5 and a less pronounced decline (densitometric analysis 50\%) in the gp120/CXCR4 interaction. However, after normalization of the band intensity (Hsp90; data not shown) there was no indication for any E2-effect on the binding efficiency between gp120 and the HIV-1 coreceptors CAR5 or CXCR4, respectively (Figure 3C, D).

\section{Recombinant GBV-C E2 Protein Interacts with gp41, while N-terminal GBV-C E2 Peptides Abrogate this Interaction}

Previously, we have shown that the target of the HIV-1inhibitory E2 peptides is most likely located on the HIV-1 particle, rather than on the cell [33]. The surface of the HIV-1 particle consists of a lipid bilayer with incorporated host cell proteins and a limited number of functional envelope (Env) trimers (on average 14 \pm 7 ) [56]. Therefore, we tested whether the HIV-1-inhibitory E2 peptides interact with trimeric HIV-1 Env proteins expressed on the surface of transfected cells. For this purpose, 293T cells were transiently transfected with an HIV-1 Env expression vector, coding for the gpl60 precursor of the CXCR4-tropic NL4-3 envelope (X4env). Binding of FITC-labeled E2 peptides was monitored by flow cytometry. Although we could observe a background attachment of P4-7 and P6-2 to mock- or vectortransfected 293T cells, there was a significant increase in the binding of P4-7 and P6-2 when cells expressed HIV-1 Env and were pretreated with $\mathrm{sCD} 4$ (Figure 4A). In contrast, the increase of binding was not observed with the negative control peptide P28. These data suggest that the HIV-inhibitory E2 peptides bind to HIV-1 Env and that this interaction seems to be CD4-dependent, since the induction of conformational changes in gp120 and/or the increase in availability of gp41 after CD4 engagement facilitates E2-binding.

In order to prove the assumption that GBV-C E2 interacts with HIV Env, subsequent binding assays were performed with plate immobilized subunits of HIV-1 envelope proteins (gp120 and gp41). To improve the significance of this experiment, here we used the whole E2-Fc fusion protein $\left(\mathrm{E} 2_{340}-\mathrm{Fc}\right)$ as a ligand. The $\mathrm{Fc}$ domain alone served as a negative control. Ninety-six-well plates were either coated with recombinant full-length gp120 (gp120 IIIB [Immuno Diagnostics, 1001-10], and gp120 MN [Immune Technology, IT-001-002MNp]), expressed in eukaryotic cells, or with gp41, expressed in E. coli, consisting of the complete ( $\mathrm{gp}_{4} 1_{\text {IIIB }}$ [Abcam, ab68129]) or truncated gp41 ectodomain (gp41 $1_{\mathrm{MN}}$ [NIH, 12027]). In gp $41_{\mathrm{MN}}$, the hydrophobic fusion peptide (FP), the transmembrane region (TM), and most of the C-terminal part of the cytoplasmic tail (CP) were omitted (illustrated in Figure 5A). Whereas no binding of the recombinant $\mathrm{E} 2_{340}-\mathrm{Fc}$ fusion protein to gp120 was observed, E2 ${ }_{340}-\mathrm{FC}_{\mathrm{C}}$ protein was shown to interact with both gp4l variants in a dose-dependent manner (Figure 4B).

To test whether GBV-C E2 binds HIV gp4l with the Nterminal domain, competition assays were performed with the $\mathrm{N}$ terminal E2 peptides P4-7 and P6-2. The results of this experiment revealed that both HIV-1-inhibitory E2 peptides abrogated the protein-protein interaction between HIV-1 gp4l and GBV-C E2 in a dose-dependent manner, whereas increasing amounts of the negative control peptides P9 and P28 had no effect (Figure 4C, left panel). The E2 peptide P9 (residue 81 to 100 of GBV-C E2, see Table S1) was chosen as an additional control [33], due to its more comparable content of cysteine and hydrophobic residues.

Noteworthy, P4-7 and P6-2 contain either two or three cysteines, respectively. To elucidate the characteristics of the E2gp41 interaction, next we tested the competition ability of peptide variants $\mathrm{P} 4-7 \mathrm{~s}$ and $\mathrm{P} 6-2 \mathrm{~s}$ in which the cysteine residues were replaced with serine. The results revealed that the serine variants P4-7s and P6-2s had lost their ability to abrogate the E2-gp41 binding, suggesting that the cysteine residues within the HIVinhibitory E2 peptides play a crucial role for gp41 recognition (Figure 4C, right panel).

In combination with these findings, we are able to show that the N-terminal region of GBV-G E2 ( residue 37 to 64 ), that is represented by the HIV-1-inhibitory peptides $\mathrm{P} 4-7$ and $\mathrm{P} 6-2$, interacts with HIV-1 gp4l and that the cysteine residues within this region appear to contribute substantially to the gp41 binding.

\section{GBV-C E2 Peptides Target the gp41 Disulfide Loop}

We next sought to localize the E2 peptide binding site within gp41. The transmembrane protein gp41 consists of several functional regions (Figure 5A). The FP, TM and CP regions of gp41 do not appear to be involved in the interaction with GBV-C $\mathrm{E} 2$ or E2 peptides, since the absence of these regions $\left(\mathrm{gp} 41_{\mathrm{MN}}\right)$ did not abrogate or decrease the E2 binding to gp41 (Figure 4B). To test whether the E2 peptides interact with either the NHR or CHR regions of gp41, which would lead to a blockade of $6-\mathrm{HB}$ formation, a competitive ELISA was performed. In this assay, peptides N36 and biotinylated C34, which present the NHR and 
A

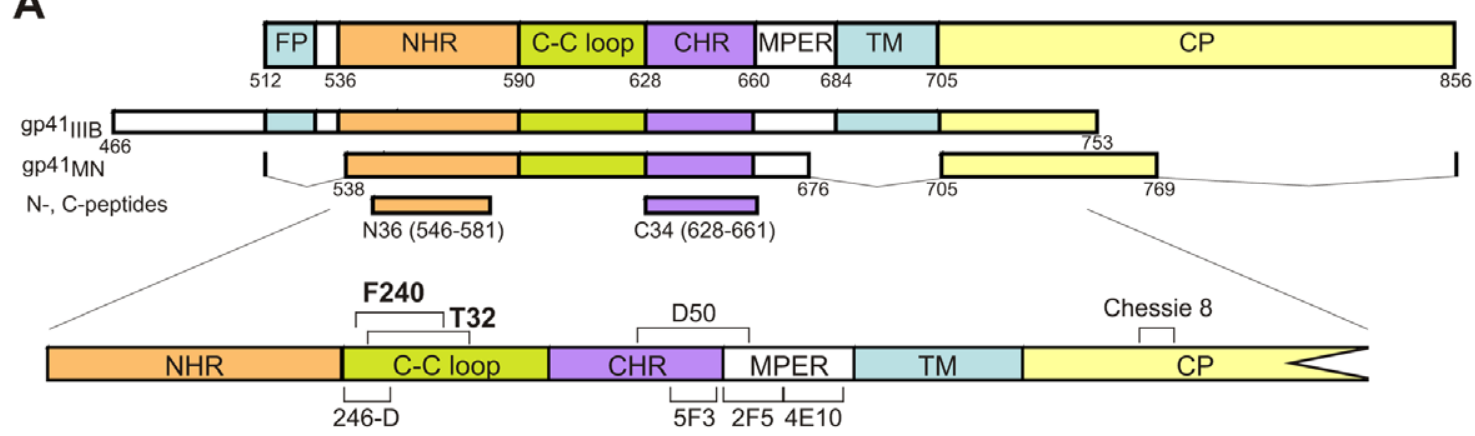

B

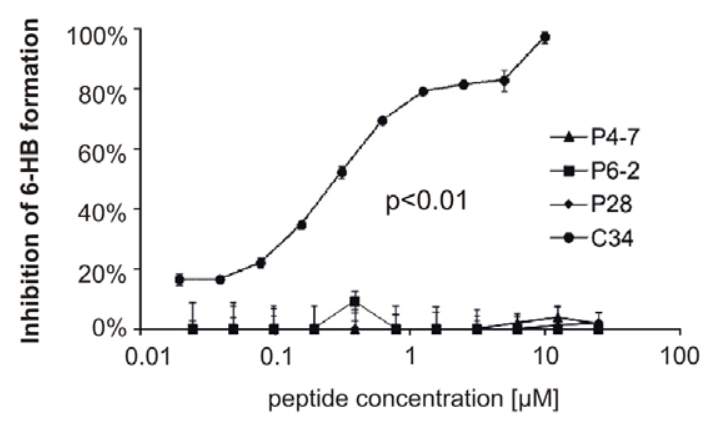

C
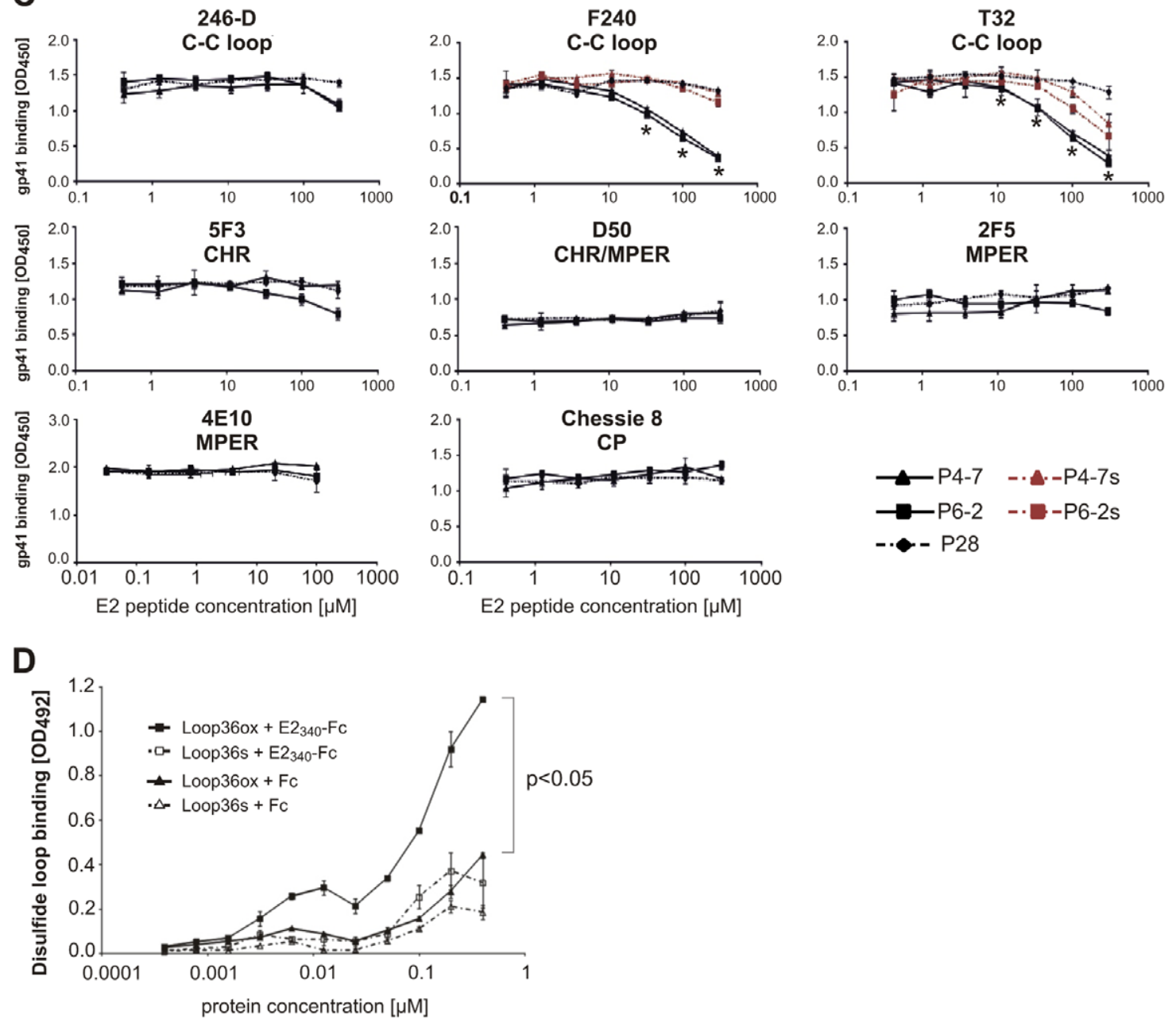
Figure 5. E2-derived peptides bind to the disulfide loop of gp41. (A) Illustration of gp41 variants (strains IIIB, MN) and peptides (N36, C34) used in ELISA as well as the binding epitopes of different monoclonal gp41 antibodies. Gp41 consists of the N-terminal fusion peptide (FP), the N-and C-heptad repeats (NHR, CHR) that are connected by the disulfide loop region (C-C loop), the membrane proximal external region (MPER), the $\alpha$-helical transmembrane-spanning domain (TM), and the cytoplasmic tail (CP). (B) Inhibitory activity on 6-Helix-Bundle (6-HB) formation of peptides P4-7, P6-2, and P28, as well as C34 as control was measured by ELISA using the NC-1 monoclonal antibody that detects the 6-HB formation between C34-biotin and N36 peptides. Each sample was tested in triplicate. This experiment was repeated twice and similar results were obtained. The statistical significance $(p<0.01)$ was achieved for all measure points (C34 vs. P28). (C) Competitive binding of E2 peptides and different gp41 targeting mAbs to immobilized recombinant gp41 $\mathrm{MN}$. Simultaneously to $\mathrm{mAb}$ incubation E2 peptides were added with increasing amounts. The graphs show average values of three independent experiments each performed in duplicate. ${ }^{*}: p<0.05$ (P4-7 or P6-2 vs. P28) (D) Binding of recombinant E2 ${ }_{340}-\mathrm{Fc}$ protein and Fc protein as control to cyclic (Loop36ox) and linear (Loop36s) peptides presenting the HIV-1 gp41 disulfide loop (residues 588-623). The graphs show average values of three independent experiments each performed in duplicate. The statistical significance $(p<0.05)$ was achieved with more than $0.003 \mu \mathrm{M}$ concentrations of each protein (Loop36ox $+\mathrm{E} 22_{340}-\mathrm{Fc}$ vs. Loop36ox $+\mathrm{Fc}$ ).

doi:10.1371/journal.pone.0054452.g005

the CHR region of gp41, respectively, interact with each other, forming stable 6 -HB structures in vitro $[57,58]$. The 6 -HB-specific mAb NC-1 was used as a capture antibody [45] and the GBV-C E2 peptides were tested for competition with N36 and C34, respectively. Neither P4-7 nor P6-2 was able to interfere with the formation of $6-\mathrm{HB}$, suggesting that the binding site of the E2 peptides is neither located in the NHR (N36) nor in the CHR (C34) regions of gp4l (Figure 5B).

To further dissect the E2 binding site within gp41, we tested whether the E2 peptides compete for gp41 binding with different monoclonal anti-gp41 antibodies with known specificities, including mAbs 246-D, F240, T32, D50, 5F3, 2F5, 4E10, and Chessie 8. Of the eight antibodies, only the gp41 interaction of F240 and T32 was inhibited in a dose-dependent manner by P4-7 and P6-2, but not by the negative control P28 (Figure 5C). No unspecific binding between the E2 peptides (P4-7 and P6-2) and the antibodies F240 or T32 was observed that could have account for the same competition results (data not shown). Therefore, we conclude that P4-7 and P6-2 compete with F240 and T32 considerably for the same binding region. F240 and T32 represent two of three tested antibodies that recognize the immunodominant disulfide loop region of gp41. Their epitopes overlap partially with each other, implying that the E2 peptides bind approximately between residues 596 and 612 of gp160. The epitopes of all tested antigp41-mAbs are shown in Figure 5A and Table S2. Again, the serine variants of P4-7 and P6-2 lost their ability to compete for the binding target with the disulfide loop antibody F240 or were at least less efficient (T32). Finally, we performed a direct binding assay with biotin-tagged 36mer gp4l disulfide loop peptides (residues from 588 to 623 according to HIV gp160 ${ }_{\mathrm{HxB} 2}$ ) and GBVC E2 340 -Fc. We immobilized via streptavidin an oxidized (closed loop) or a linear variant of the disulfide loop, in which the cysteine residues were replaced with serine (Table $\mathrm{S} 1$ ) onto plates and the binding of graded concentrations of GBV-C E2 $340-\mathrm{FC}$ was monitored with HRP-anti-human antibodies. Indeed, a distinct binding of recombinant $\mathrm{E} 2{ }_{340}-\mathrm{Fc}$ protein to the gp41 disulfide loop peptides was evident in a dose dependent manner, whereas for the Fc control only a low background binding was observed. The binding of $\mathrm{E} 2{ }_{340}-\mathrm{Fc}$ was clearly diminished when the linear serine variant of the gp4l disulfide loop was tested (Figure 5D).

\section{HIV-1 Inhibitory GBV-C E2 Peptides Bear Local Similarities to the gp120 N-terminus that is Part of the gp120-gp41 Interface}

Specific intra- and intermolecular interactions within HIV-1 Env are essential for the formation of a native and functional HIV1 envelope trimer, as well as for concerted conformational changes during the entry process. Therefore, peptides or small molecules that mimic Env regions involved in these interactions are potential inhibitors of the formation of properly folded tertiary and quaternary Env structures. Examples of this strategy are potent peptide fusion inhibitors, which resemble the gp41 NHR or CHR sequences, including enfuvirtide (T20) [59], SJ-2176 [60], or N36 [61]. Hence, we performed a similarity search between the GBVC E2 ectodomain and HIV-1 gpl60 and identified a local similarity of two sequence stretches of the GBV-C E2 N-terminus to the HIV-1 gp120 N-terminus (Figure 6A). The sequence stretches 33-46 and 54-70 of E2 exhibit sequence similarities of $85.7 \%$ and $76.5 \%$ to the N-terminus of gp 120 . This region of similarity also agrees very well with the sequence region spanned by E2-derived peptides (residues 29-72) that proved to be potent in HIV-entry inhibition [33].

We have also put this sequence similarity in the structural context of gp120 and gp41. High-resolution structural information on gp120-gp41 interaction remains elusive (reviewed in [36]). However, several mutagenesis studies and a recent crystal structure of gp120 suggest that the N- and C-termini of gp120 interact predominantly with the disulfide loop region of gp41 $[62,63]$. Interestingly, the N-terminal sequence stretch of gp 120 that has been proposed to be involved in the gp120-gp41 interaction is located within the gp120 region that resembles the HIV-1-inhibitory N-terminal GBV-C E2 peptides (Figure 6B). Furthermore, residues within the gp4l trimer, which have been proposed to be involved in the gp120 interface, are located near or within the epitopes of the two antibodies T32 and F240 whose interaction with gp41 was disrupted by the E2 peptides $\mathrm{P} 4-7$ and P6-2 (Figure 6C).

To prove the assumption that a similarity between the GBV-C E2 and HIV gp120 N-termini enables E2 or E2 peptides to bind to gp41 in a gp120 manner, a corresponding N-terminal gp120 peptide should be able to disturb the E2-gp41 interaction. Therefore, we assessed in E2-gp41 competition assays the effect of a gp120 peptide (N35, gp120 residue 31 to 65) that includes the respective E2-similarity region (Figure 7). We observed that N35 efficiently competed with E2 for gp41 binding, implying that E2 and gp120 share the same gp41 interaction site. Not surprisingly, the gp41 affinity was more pronounced for N35 $\left(\mathrm{IC}_{50}: 0.7 \mu \mathrm{M}\right)$ than for the E2 peptides $\left(\mathrm{IC}_{50} \mathrm{~s}: 7.0 \mu \mathrm{M}\right.$ for P6-2 and $11.7 \mu \mathrm{M}$ for P4-7). The C54S variant of this peptide (N35s) still abrogated the E2-gp41 interaction in a dose dependent manner, but less efficiently than the wild-type $\mathrm{N} 35$ peptide $\left(\mathrm{IC}_{50}: 4.6 \mu \mathrm{M}\right)$. Together, these results strongly support the hypothesis that a mimicry phenomenon between the $\mathrm{N}$-termini of the non-related viral glycoproteins $\mathrm{E} 2_{\mathrm{GBV}-\mathrm{C}}$ and gp120 $\mathrm{HIV}$, enables the E2 N-terminus to approach the gp120 binding site on gp41 that is believed to be the disulfide loop region.

Since no structural information on the GBV-C E2 protein is currently available, we performed structure predictions and globularity analyses of the GBV-C E2 protein in order to get an idea whether the $\mathrm{N}$-terminus of $\mathrm{E} 2$ is accessible to the interaction with HIV-1 Env involved in membrane fusion. Our analysis consistently suggests the presence of a folded region spanning 
A

$85.7 \%$ similarity $(42.9 \%$ identity) in 14 aa overlap

$76.5 \%$ similarity $(23.5 \%$ identity) in 17 aa overlap

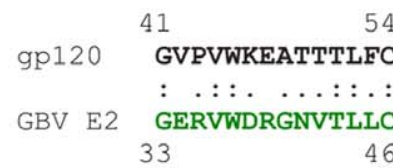

10

GAPASVLGSRPFDYGLKWQSCSCRANGSRIPTGERVWDRGNVTLLCDCPNGPWVWVPAFCQAVGWGDPITHW E2

$\begin{array}{llll} & 4 \\ & & \end{array}$

B

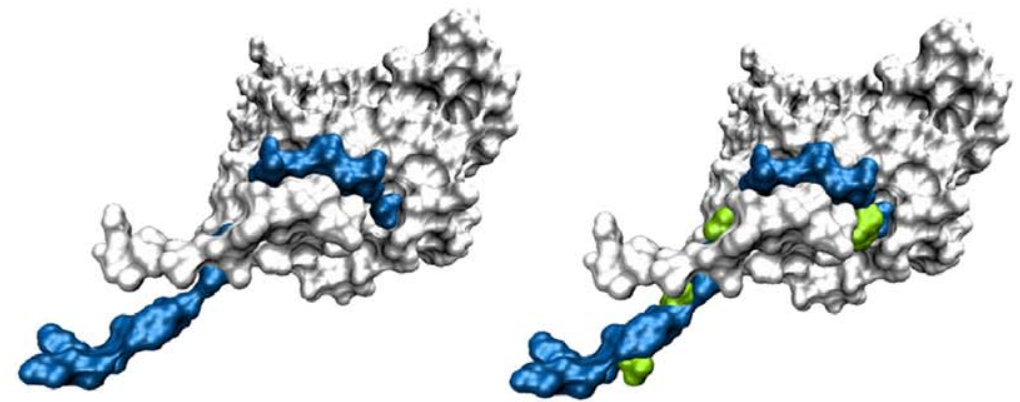

C
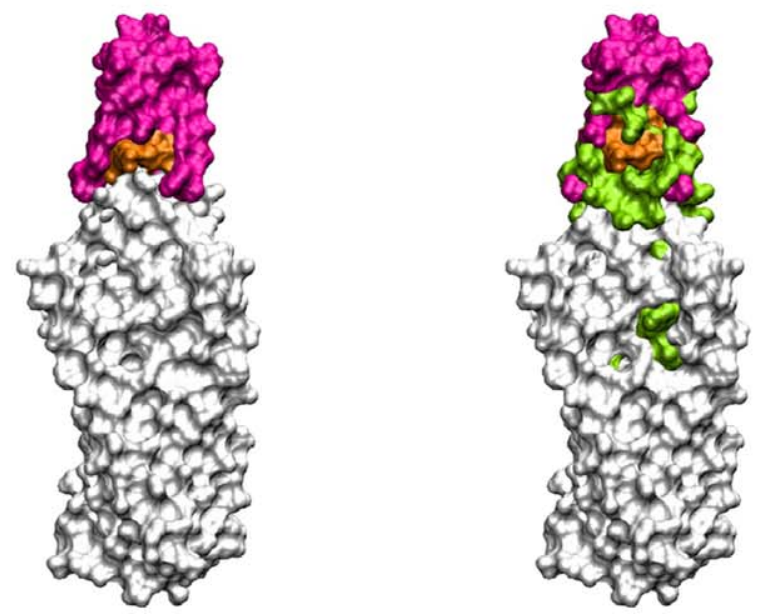

Figure 6. Local similarities between the N-termini of gp120 and E2. (A) Similarities of the two local sequences in the N-termini of HIV-1 gp120 and GBV-C E2. The detected E2 stretches (residues 33-46 and 54-70) are shown in the context of the entire E2 N-terminus and are color coded in green and orange, respectively. Illustrated are the sequences of the peptides that proved to be potent in HIV-1 entry inhibition [33]. These peptides almost exclusively cover the E2 sequence stretch that exhibits similarities to the gp120 N-terminus. Molecules are shown in space-filled presentation and the functionally important regions are colored. (B) Structure of monomeric gp120. The N-terminal region of gp120 that exhibits local similarity with the active E2-derived peptides is shown in blue. Residues that were deduced from mutational analyses to be relevant for the gp120-gp41 interaction (reviewed in [36]) are additionally shown in green. (C) Structure of trimeric gp41. The disulfide-bonded loops that are recognized by the T32 antibody (residues 596-612) are shown in red. Residues 592-596 additionally present in the F240 epitope are shown in orange. Residues that were deduced from mutational analyses to be relevant for the gp120-gp41 interaction (reviewed in [36]) are additionally shown in green. The coordinates for structure presentations were taken from PDB entries 3JWD and 2EZO for gp120 and gp41, respectively. doi:10.1371/journal.pone.0054452.g006 


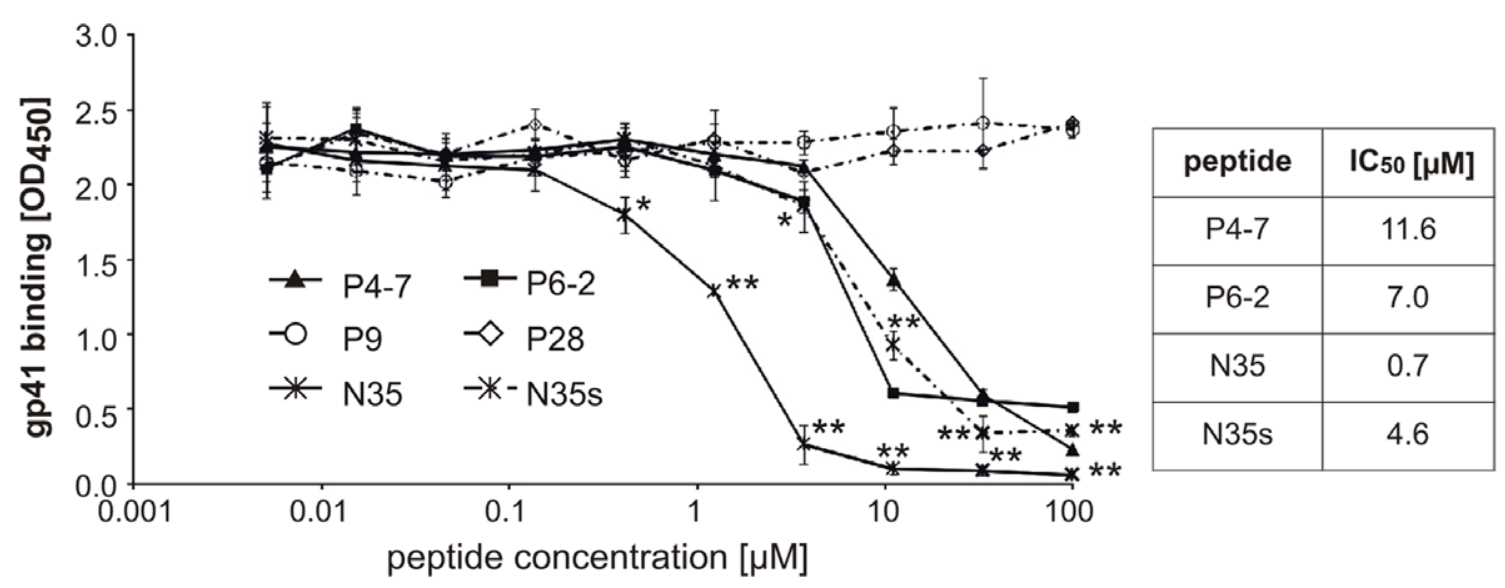

Figure 7. The N-termini of GBV-C E2 and HIV-1 gp120 share the same binding region within the gp41. Competitive binding of E2 and gp120 peptides (N35, N35s) with recombinant E2 $340-\mathrm{Fc}$ protein to immobilized recombinant gp $41_{\mathrm{MN}}$. Simultaneously to $\mathrm{E} 2_{340}-\mathrm{Fc}$ incubation peptides of E2 or gp120 were added with increasing amounts. The graphs show average values of three independent experiments each performed in duplicate. *: $p<0.05 ;{ }^{* *}: p<0.01$ (N35 or N35s vs. P28; P4-7 or P6-2 vs. P28 [data not shown]). doi:10.1371/journal.pone.0054452.g007

residues 76 to 195 of GBV-C E2. The remaining extracellular part, in particular the $\mathrm{N}$-terminal region including amino acids 1 to 75 that comprise the HIV-1-inhibitory domain, does not contain significant amounts of regular secondary structure and is therefore predicted to form no globular conformation (Figure 8). Consequently, the E2 N-terminus is likely to be rather flexible which could plausibly account for its interaction with gp4l during HIV-1 entry.

\section{Discussion}

In this study, we have explored the molecular mechanism underlying the previously reported interference with HIV-1 entry by two overlapping peptides derived from the N-terminal part of the GBV-C envelope protein E2. We are able to demonstrate that the E2 peptides interfere with late stages of HIV-1 entry. This notion is evidenced by the observations that neither the cell surface expression of HIV-1 receptors, nor the binding of gp120 to CD4 and coreceptors, respectively, appears to be affected. Instead, HIV-inhibitory E2 peptides showed full activity on HIV entry at a post-binding stage. In agreement with these findings, binding experiments revealed an interaction between E2 or E2 peptides and the HIV-1 transmembrane protein gp41 responsible for late membrane fusion activity.

In an earlier study, we demonstrated that the HIV-1 inhibitory region ranges from residue 29 to 72 of the GBV-C E2 N-terminus [33]. In this study we show that the E2 peptides P4-7 and P6-2 (representing E2 residues 37 to 64) compete with E2 protein for gp4l binding. Therefore, we assume that the HIV-inhibitory region or at least the inner domain ranging from residue 37 to 64 reflects a gp41-binding site of GBV-C E2. Interestingly, the sequence stretch covered by the HIV-inhibitory peptides includes the strongest conserved part of the nonglobular N-terminus of related flaviviridae E2 proteins (Figure S1). In particular, several cysteines (C46, C48, C60) and tryptophans (W55, W65) are highly conserved among GBV-C and GBV-A isolates, suggesting that the respective E2 proteins might also exhibit a similar anti-lentiviral activity. The alignment shown in Figure $\mathrm{S} 1$ also reveals that the sequence conservation is less pronounced for the more distantly related E2 proteins of GBV-B and GBV-D. The N-termini of the E2 proteins from GBV-C and $\mathrm{HCV}$ show no detectable sequence homology at all rendering functional similarity rather unlikely.
The results of several experiments aimed at dissecting the E2binding domain within gp41 suggest that E2 interacts with the gp41 disulfide loop region. The gp4l disulfide loop region structurally connects the NHR and CHR domains and contains two conserved cysteines [64]. Noteworthy, the N-terminal E2 region contains three cysteine residues (Cys46, Cys48 and Cys60) as well. Previously we could show that variants of the E2 peptides (P4-7s and P6-2s), in which cysteines were replaced with serine residues, lost their HIV-inhibitory capacity [33]. In agreement with these observations, in this study, P4-7s and P6-2s lost their ability to compete with E2 for gp4lbinding. In addition, the cysteine residues within the disulfide loop peptide appeared to be crucial for the interaction with recombinant E2 protein. This implies that the cysteine residues within the HIV-inhibitory E2 peptides may interfere with the oxidation state of the respective cysteines in the gp41 disulfide loop region. A variety of evidence suggests that a number of viral envelope glycoproteins depend on a dynamic thiol/disulfide balance to mediate virus-cell fusion (reviewed in [65]). For HIV-1 it has been shown that after CD4 binding a cell surface-associated reductase activity leads to cleavage of disulfide bonds at least within gp120 and that this event is obligatory for triggering membrane fusion [66]. However, the insights into the mechanistic role of the disulfide loop cysteines for the fusion reaction are still limited and need further evaluation. Future studies will show, whether reducing agents would change the interference effects of GBV-C E2-derived peptides.

Based on cryo-EM structural information, the gp4l transmembrane protein is expected to be at least partially buried in the trimeric gp4l-gp120 structure [67]. Thus, the transient states of gp4l appears to be valid HIV-1 inhibitor targets, as evidenced by a number of known HIV-1 fusion inhibitors, including gp41targeted peptides and low-molecular-weight inhibitors. These inhibitors typically bind to the NHR or CHR regions during the prehairpin stage in order to prevent the formation of the 6-HB. However, Münch et al. [42] isolated the natural HIV-1 entry inhibitor VIRIP from human hemofiltrates, targeting the gp41 fusion peptide, and broad neutralizing antibodies, like 2F5, 4E10, and $\mathrm{Z} 13 \mathrm{e} 1$, bind the MPER, an epitope that is also transiently accessible at a late stage of HIV-1 entry. Our results show that the interaction of a peptide with the gp4l disulfide loop region can block HIV-1 fusion, thus introducing the gp4l disulfide loop as a new and promising target for HIV-1 entry inhibition. The 


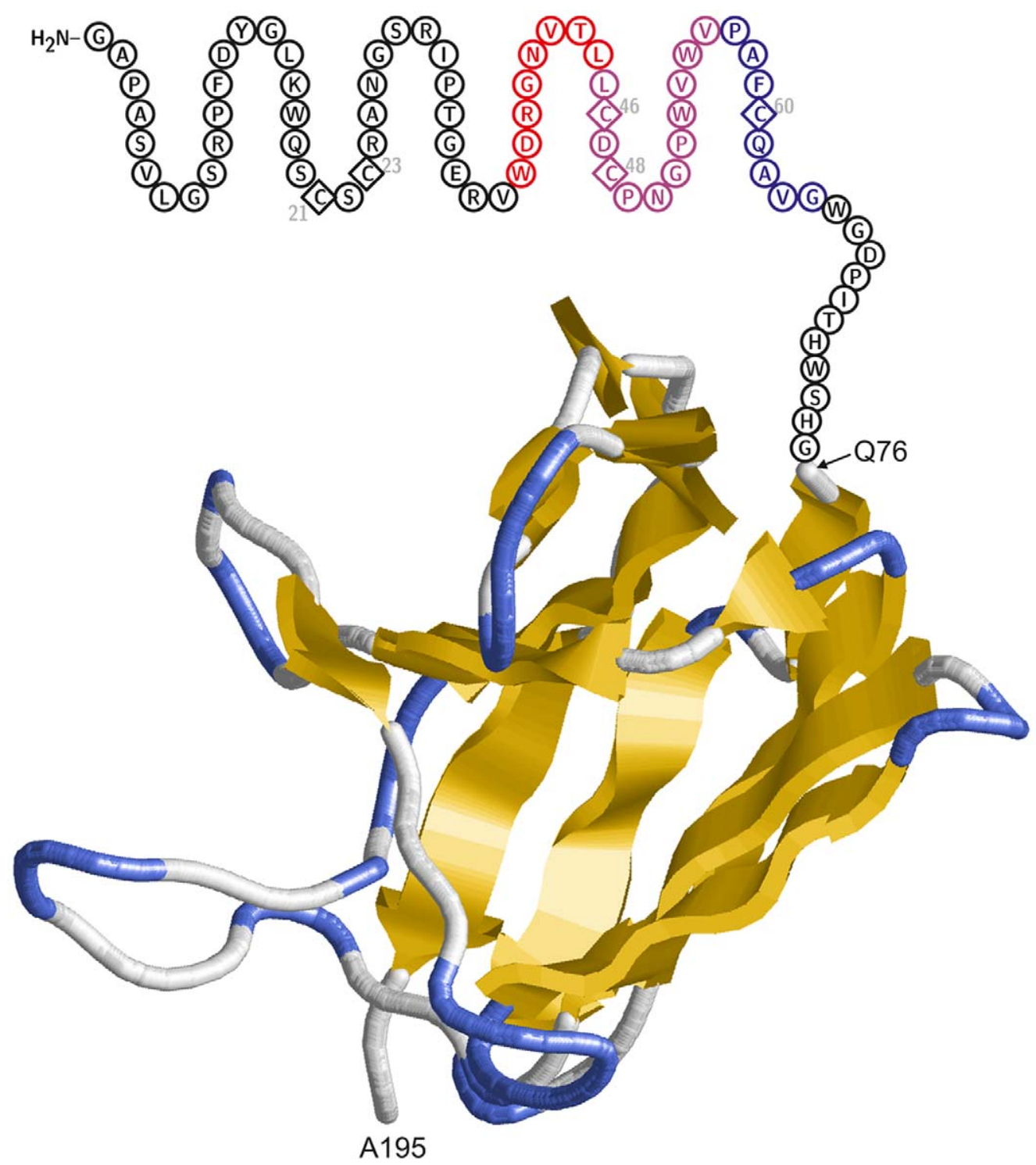

Figure 8. Model of the N-terminal region (residues 1-195) of the E2-protein. The globular Ig-fold domain (residues 76-195), for which a structural model could be generated, is shown in backbone presentation and colored according to the secondary structure type. The $\mathrm{N}$-terminus (residues 1-75), which is not predicted to adopt a globular three-dimensional structure, is schematically depicted as circles indicating the identity of the respective amino acids. Cysteines, which may form disulfide bonds, are shown as diamonds and their sequence position is indicated. Residues belonging to the P4-7 and P6-2 peptides investigated in the present study are highlighted in red and blue, respectively. Overlapping residues present in both peptides are shown in magenta. doi:10.1371/journal.pone.0054452.g008

relevance of disulfide loop-targeting HIV-1 inhibitors is further supported by two reports that describe low-molecular-weight HIV-1 inhibitors causing resistance-conferring mutations within that disulfide loop region $[68,69]$.

The gp41 disulfide loop is an immunodominant region termed cluster I [70], suggesting that this region is permanently or at least transiently accessible [71]. However, unlike the E2 peptides studied here, antibodies directed against cluster I appear to have no relevant HIV-1 neutralizing capacity. The difference of action between the cluster I antibodies and E2 peptides is an interesting question that needs further investigation. One possible explanation may be the fact that steric forces prevent globular antibodies to gain access to the gp41 disulfide loops at the right time, whereas peptides may have sufficient flexibility for this purpose. However, it is tempting to speculate whether in vivo the intact E2 ectodomain is able to reach the gp4l disulfide loop in a peptide-like manner? While no structural information on E2 is available, our computerbased structural analysis revealed that the $\mathrm{N}$-terminal region of $\mathrm{E} 2$ (residues 1 to 75) appears to be largely unstructured, suggesting that this protein domain may be sufficiently flexible to interact with the disulfide loop of gp41 during HIV-1 entry. In this context, experiments addressing the amount of circulating E2 (virus- versus possibly exosome-associated or processed E2) in plasma of GBV-C coinfected HIV-positive individuals appear appropriate.

The surface glycoprotein gp120 and the transmembrane gp41 subunits are noncovalently associated on the viral surface. However, little is known at the atomic level about the critical gp120-gp41 interface. Several mutagenesis studies suggest that the $\mathrm{N}$ - and C-termini of gp120 interact with the disulfide loop of gp41 and flanking parts of the NHR and CHR regions [62,63,72-74]. 
However, our knowledge about the dynamic gp120-gp41 interplay during the different phases of HIV-1 entry is sparse. We do not know which parameters allow gp120 to stabilize gp4l in a metastable conformation in the unliganded trimer and after CD4 engagement but support gp41 rearrangements after coreceptor binding. A recent crystal structure of an HIV-1 gp120 core with intact gp120 N- and C-termini revealed three topologically separate and structurally plastic layers [75]. The conformational mobility of these layers together appears to be relevant for buffering movements of gp 120 from gp41. It should be noted that the extended gp120 N-terminus appeared particularly flexible, such that interactions with gp4l in the viral spike could easily induce termini movements [75]. This plasticity of the termini might also offer an explanation for the fact that the interactions of the gp120 N-terminus with gp4l can be mimicked by flexible peptides. Computational and experimental data from this study indicate that N-terminal GBV-C E2 peptides mimic the HIV-1 gp120 N-terminus and are therefore able to compete with gp120 for binding to the disulfide loop region of gp4l. Competition experiments confirmed that E2 peptides ( $\mathrm{P} 4-7$ and $\mathrm{P} 6-2)$ and a corresponding $\mathrm{N}$-terminal gp120 peptide ranging from residue 31 to 65 of gp120 share the same binding region in gp41. Therefore, we conclude that the respective E2 peptides may displace gp120 and disturb the interface between gp120 and gp41 after CD4 or coreceptor binding. This phenomenon may result in impeding the concerted interplay between stabilization (native, unbound state) and destabilization (receptor-bound and following states) of the gp120-gp41 complex, which is critical for HIV-1 entry to take its proper course. In particular, binding of E2 or E2-derived peptides to the gp41 disulfide loop may influence the proper disulfide formation of gp41, the flexibility of gp41 that is needed to promote the 6 -HB formation, or the membrane accessibility of gp41 that is essential for lipid mixing. However, the elucidation of the precise mode of action of the disulfide loop targeting peptides will be an interesting subject for future evaluations. In this context, it would be interesting to consider chimeric peptides that incorporate sequences of GBV-C E2 and the HIV-1 N-terminus of gp120 as a new approach to enhance the antiretroviral activity of disulfide loop-targeted peptide inhibitors.

Previously, Herrera et al. [76] reported that peptides derived from the N-terminus of GBV-C E2 (ranging from residues 31 to 78), as well as several more downstream regions of E2, interact with the HIV-1 fusion peptide, resulting in suppression of HIV-1 replication. Our data do not confirm the association of the GBV-C E2 N-terminus with the HIV-1 fusion peptide during HIV-1 entry. However, it is very plausible that other E2 regions interact with the $\mathrm{N}$-terminal gp41 fusion peptide, in addition to the interaction of the GBV-C E2 N-terminus with the gp41 disulfide loop proposed in this study. Most recently, Xiang et al. [35] reported that the GBV-C E2 protein or a peptide representing the E2 residues 276 to 292 interfered with HIV-1 entry, when expressed in Jurkat cells. However, when added to cells the respective peptide did not inhibit HIV-1 entry unless it was fused to Tat for cellular uptake. Taken together, these observations support the relevance of GBVC E2 for HIV-1 entry interference but suggest that additionally to the $\mathrm{N}$-terminus at least the $\mathrm{C}$-terminal part of the E2 ectodomain is involved in HIV-1 entry inhibition. This may also explain the modest effect on CXCR4 cell surface presentation upon expression of full length E2 that we do not see after cell incubation with

\section{References}

1. Feucht HH, Fischer L, Sterneck M, Broelsch CE, Laufs R (1997) GB virus C transmission by blood products. Lancet 349: 435.
$\mathrm{N}$-terminal E2 peptides. However, it needs further evaluation to what extent E2-presenting GBV-C particles or GBV-C infected cells via a bystander effect, proposed by Xiang et al. [35], contribute to the E2-mediated HIV-1 entry impairment.

In conclusion, we propose a new strategy of HIV-1 entry inhibition based on sequence resemblance between the N-termini of GBV-C E2 and HIV-1 gp120. Our results demonstrate that peptides targeting the gp41 disulfide loop are able to inhibit HIV-1 fusion, introducing a novel design concept for HIV-1 fusion inhibitors.

\section{Supporting Information}

Figure S1 Multiple sequence alignment of related E2 proteins. Multiple sequence alignment of E2 proteins from GBV-C (black), GBV-A (green), GBV-B (red), and GBV-D (blue). The GBV-C isolate used in the present study is shown in the first line and the sequence stretch covered by the active peptides is underlined. The second line shows a distantly related E2 protein from chimpanzee GBV-C to highlight the sequence divergence within the GBV-C isolates. Conserved cysteines and aromatic residues are shown as bold letters.

(TIF)

Table S1 Sequences of synthetic GBV-G E2 and HIV-1 peptides. *Numbering follows GBV-C E2 GenBank accession no. AF121950 or HIV-1 HxB2 gp160 (HIV databases: http://www. hiv.lanl.gov), respectively $\mathrm{X}$ : $\varepsilon$-aminohexanoic acid.

(DOG)

Table S2 Specificities of gp41 targeting antibodies. *Numbering follows HIV-1 HXB2 gp160 (HIV databases: http:// www.hiv.lanl.gov). Bold letters represent the core of the epitope, and flanking amino acids may contribute to binding efficiency. (DOC)

\section{Acknowledgments}

We thank Lu Lu (Fudan University, Shanghai, China) for experimental help, Carsten Münk (University Hospital Düsseldorf, Germany) for providing the BlaM-Vpr expression plasmid, Brigitte Biesinger (Institute for Virology, Erlangen, Germany) for providing the anti-Hsp90 antibody, and Kristin Kassler (Institute of Biochemistry, Erlangen, Germany) for help with figure preparation. The following reagents were obtained through the NIH AIDS Research and Reference Reagent Program, Division of AIDS, NIAID, NIH: TZM-bl from Dr. John C. Kappes, Dr. Xiaoyun Wu and Tranzyme Inc; antibodies b12 from Dr. Dennis Burton and Carlos Barbas; VRC01 from Dr. John Mascola; 2F5 and 4E10 from Dr. Hermann Katinger; B4 from United Biomedical Inc.; F240, F425 B4e8 and F425 B4al from Dr. Marshall Posner and Dr. Lisa Cavacini; 246-D and 44752D from Dr. Susan Zolla-Pazner; T32 and D50 from Dr. Patricia Earl, NIAID; Chessie 8 from Dr. George Lewis; sCD4-183 (2-domain) from Pharmacia, Inc.; Bicyclam JM-2987 (hydrobromide salt of AMD-3100); Tak-779 [77] Maraviroc; HIV-1 BaL gp120; HIV-1 $_{\text {96ZM651 }}$ gp120; HIV-1 gp41 MN; HIV-1 gp120 CM envelope protein; Fc-gp120 from Aymeric de Parseval and Dr. John H. Elder.

\section{Author Contributions}

Conceived and designed the experiments: KE HS S. Jiang JE BF HR. Performed the experiments: KE SM HS PZ AG. Analyzed the data: KE SM HS S. Jung S. Jiang AG JE BF HR. Contributed reagents/materials/ analysis tools: HS S. Jiang JE BF HR. Wrote the paper: KE HS JE HR.

2. Lefrere JJ, Roudot-Thoraval F, Morand-Joubert L, Brossard Y, Parnet-Mathieu F, et al. (1999) Prevalence of GB virus type C/hepatitis G virus RNA and of anti- 
E2 in individuals at high or low risk for blood-borne or sexually transmitted viruses: evidence of sexual and parenteral transmission. Transfusion 39: 83-94.

3. Mohr EL, Stapleton JT (2009) GB virus type C interactions with HIV: the role of envelope glycoproteins. J Viral Hepat 16: 757-768.

4. Stapleton JT, Foung S, Muerhoff AS, Bukh J, Simmonds P (2011) The GB viruses: a review and proposed classification of GBV-A, GBV-C (HGV), and GBV-D in genus Pegivirus within the family Flaviviridae. J Gen Virol 92: 233 246 .

5. Alter HJ (1997) G-pers creepers, where'd you get those papers? A reassessment of the literature on the hepatitis $\mathrm{G}$ virus. Transfusion 37: 569-572.

6. Stapleton JT (2003) GB virus type G/Hepatitis G virus. Semin Liver Dis 23: $137-148$.

7. Leary TP, Muerhoff AS, Simons JN, Pilot-Matias TJ, Erker JC, et al. (1996) Sequence and genomic organization of GBV-C: a novel member of the flaviviridae associated with human non-A-E hepatitis. J Med Virol 48: 60-67.

8. Linnen J, Wages J Jr., Zhang-Keck ZY, Fry KE, Krawczynski KZ, et al. (1996) Molecular cloning and disease association of hepatitis $\mathrm{G}$ virus: a transfusiontransmissible agent. Science 271: 505-508.

9. Simons JN, Leary TP, Dawson GJ, Pilot-Matias TJ, Muerhoff AS, et al. (1995) Isolation of novel virus-like sequences associated with human hepatitis. Nat Med 1: 564-569.

10. Belyaev AS, Chong S, Novikov A, Kongpachith A, Masiarz FR, et al. (1998) Hepatitis $\mathrm{G}$ virus encodes protease activities which can effect processing of the virus putative nonstructural proteins. J Virol 72: 868-872.

11. Tacke M, Schmolke S, Schlueter V, Sauleda S, Esteban JI, et al. (1997) Humoral immune response to the $\mathrm{E} 2$ protein of hepatitis $\mathrm{G}$ virus is associated with longterm recovery from infection and reveals a high frequency of hepatitis $G$ virus exposure among healthy blood donors. Hepatology 26: 1626-1633.

12. Feucht HH, Schroter M, Zollner B, Polywka S, Laufs R (1999) Age-dependent acquisition of hepatitis $\mathrm{G}$ virus/GB virus $\mathrm{C}$ in a nonrisk population: detection of the virus by antibodies. J Clin Microbiol 37: 1294-1297.

13. Heringlake S, Ockenga J, Tillmann HL, Trautwein C, Meissner D, et al. (1998) $\mathrm{GB}$ virus $\mathrm{C} /$ hepatitis $\mathrm{G}$ virus infection: a favorable prognostic factor in human immunodeficiency virus-infected patients? J Infect Dis 177: 1723-1726.

14. Lefrere JJ, Roudot-Thoraval F, Morand-Joubert L, Petit JC, Lerable J, et al. (1999) Carriage of GB virus C/hepatitis G virus RNA is associated with a slower immunologic, virologic, and clinical progression of human immunodeficiency virus disease in coinfected persons. J Infect Dis 179: 783-789.

15. Tillmann HL, Heiken H, Knapik-Botor A, Heringlake S, Ockenga J, et al. (2001) Infection with GB virus C and reduced mortality among HIV-infected patients. N Engl J Med 345: 715-724.

16. Toyoda H, Fukuda Y, Hayakawa T, Takamatsu J, Saito H (1998) Effect of GB virus $\mathrm{C} /$ hepatitis $\mathrm{G}$ virus coinfection on the course of HIV infection in hemophilia patients in Japan. J Acquir Immune Defic Syndr Hum Retrovirol 17: 209-213.

17. Williams CF, Klinzman D, Yamashita TE, Xiang J, Polgreen PM, et al. (2004) Persistent GB virus C infection and survival in HIV-infected men. N Engl J Med 350: 981-990.

18. Xiang J, Wunschmann S, Diekema DJ, Klinzman D, Patrick KD, et al. (2001) Effect of coinfection with GB virus $\mathrm{C}$ on survival among patients with HIV infection. N Engl J Med 345: 707-714.

19. Yeo AE, Matsumoto A, Hisada M, Shih JW, et al. (2000) Effect of hepatitis G virus infection on progression of HIV infection in patients with hemophilia. Multicenter Hemophilia Cohort Study. Ann Intern Med 132: 959-963.

20. Zhang W, Chaloner K, Tillmann HL, Williams CF, Stapleton JT (2006) Effect of early and late GB virus $\mathrm{C}$ viraemia on survival of HIV-infected individuals: a meta-analysis. HIV Med 7: 173-180.

21. Supapol WB, Remis RS, RaboudJ, Millson M, Tappero J, et al. (2008) Reduced mother-to-child transmission of HIV associated with infant but not maternal GB virus C infection. J Infect Dis 197: 1369-1377.

22. Vahidnia F, Petersen M, Stapleton JT, Rutherford GW, Busch M, et al. (2012) Acquisition of GB Virus Type $\mathrm{C}$ and Lower Mortality in Patients With Advanced HIV Disease. Clin Infect Dis 55: 1012-1019.

23. George SL, Varmaz D, Stapleton JT (2006) GB virus C replicates in primary T and B lymphocytes. J Infect Dis 193: 451-454.

24. Jung S, Knauer O, Donhauser N, Eichenmuller M, Helm M, et al. (2005) Inhibition of HIV strains by GB virus $\mathrm{C}$ in cell culture can be mediated by CD4 and CD8 T-lymphocyte derived soluble factors. AIDS 19: 1267-1272.

25. Maidana-Giret MT, Silva TM, Sauer MM, Tomiyama H, Levi JE, et al. (2009) $\mathrm{GB}$ virus type $\mathrm{C}$ infection modulates T-cell activation independently of HIV-1 viral load. AIDS 23: 2277-2287.

26. Moenkemeyer M, Schmidt RE, Wedemeyer H, Tillmann HL, Heiken H (2008) GBV-C coinfection is negatively correlated to Fas expression and Fas-mediated apoptosis in HIV-1 infected patients. J Med Virol 80: 1933-1940.

27. Nattermann J, Nischalke HD, Kupfer B, Rockstroh J, Hess L, et al. (2003) Regulation of CG chemokine receptor 5 in hepatitis $\mathrm{G}$ virus infection. AIDS 17: 1457-1462.

28. Nunnari G, Nigro L, Palermo F, Attanasio M, Berger A (2003) Slower progression of HIV-1 infection in persons with $\mathrm{GB}$ virus $\mathrm{C}$ co-infection correlates with an intact T-helper 1 cytokine profile. Ann Intern Med 139: 2630 .

29. Schwarze-Zander C, Neibecker M, Othman S, Tural C, et al. (2010) GB virus C coinfection in advanced HIV type-1 disease is associated with low CCR5 and CXCR4 surface expression on CD4(+) T-cells. Antivir Ther 15: 745-752.
30. Xiang J, George SL, Wunschmann S, Chang Q Klinzman D, et al. (2004) Inhibition of HIV-1 replication by GB virus $\mathrm{C}$ infection through increases in RANTES, MIP-1alpha, MIP-1beta, and SDF-1. Lancet 363: 2040-2046.

31. Xiang J, McLinden JH, Chang Q, Kaufman TM, Stapleton JT (2006) An 85-aa segment of the GB virus type C NS5A phosphoprotein inhibits HIV-1 replication in CD4+ Jurkat T cells. Proc Natl Acad Sci U S A 103: 1557015575.

32. Jung S, Eichenmuller M, Donhauser N, Neipel F, Engel AM, et al. (2007) HIV entry inhibition by the envelope 2 glycoprotein of GB virus C. AIDS 21: 645647.

33. Koedel Y, Eissmann K, Wend H, Fleckenstein B, Reil H (2011) Peptides derived from a distinct region of $\mathrm{GB}$ virus $\mathrm{C}$ glycoprotein $\mathrm{E} 2$ mediate strain-specific HIV-1 entry inhibition. J Virol 85: 7037-7047.

34. Rydze RT, Xiang J, McLinden JH, Stapleton JT (2012) GB virus type C infection polarizes T-cell cytokine gene expression toward a Th1 cytokine profile via NS5A protein expression. J Infect Dis 206: 69-72.

35. Xiang J, McLinden JH, Kaufman TM, Mohr EL, Bhattarai N, et al. (2012) Characterization of a peptide domain within the GB virus $\mathrm{C}$ envelope glycoprotein (E2) that inhibits HIV replication. Virology 430: 53-62.

36. Caffrey M (2011) HIV envelope: challenges and opportunities for development of entry inhibitors. Trends Microbiol 19: 191-197.

37. Maddon PJ, Dalgleish AG, McDougal JS, Clapham PR, Weiss RA, et al. (1986) The T4 gene encodes the AIDS virus receptor and is expressed in the immune system and the brain. Cell 47: 333-348.

38. Alkhatib G, Combadiere C, Broder CG, Feng Y, Kennedy PE, et al. (1996) CG CKR5: a RANTES, MIP-1alpha, MIP-1beta receptor as a fusion cofactor for macrophage-tropic HIV-1. Science 272: 1955-1958.

39. Feng Y, Broder CC, Kennedy PE, Berger EA (1996) HIV-1 entry cofactor: functional cDNA cloning of a seven-transmembrane, $G$ protein-coupled receptor. Science 272: 872-877.

40. Tilton JC, Doms RW (2010) Entry inhibitors in the treatment of HIV-1 infection. Antiviral Res 85: 91-100.

41. Cavrois M, De NC, Greene WC (2002) A sensitive and specific enzyme-based assay detecting HIV-1 virion fusion in primary T lymphocytes. Nat Biotechnol 20: $1151-1154$

42. Munch J, Standker L, Adermann K, Schulz A, Schindler M, et al. (2007) Discovery and optimization of a natural HIV-1 entry inhibitor targeting the gp41 fusion peptide. Cell 129: 263-275.

43. Munk C, Wei G, Yang OO, Waring AJ, Wang W, et al. (2003) The thetadefensin, retrocyclin, inhibits HIV-1 entry. AIDS Res Hum Retroviruses 19: 875-881.

44. He Y, Cheng J, LiJ, Qi Z, Lu H, et al. (2008) Identification of a critical motif for the human immunodeficiency virus type 1 (HIV-1) gp41 core structure: implications for designing novel anti-HIV fusion inhibitors. J Virol 82: 6349 6358.

45. Jiang S, Lin K, Lu M (1998) A conformation-specific monoclonal antibody reacting with fusion-active gp 41 from the human immunodeficiency virus type 1 envelope glycoprotein. J Virol 72: 10213-10217.

46. Jiang S, Lu H, Liu S, Zhao Q, He Y, et al. (2004) N-substituted pyrrole derivatives as novel human immunodeficiency virus type 1 entry inhibitors that interfere with the gp41 six-helix bundle formation and block virus fusion. Antimicrob Agents Chemother 48: 4349-4359.

47. Linding R, Russell RB, Neduva V, Gibson TJ (2003) GlobPlot: Exploring protein sequences for globularity and disorder. Nucleic Acids Res 31: 37013708.

48. Deleage G, Blanchet G, Geourjon C (1997) Protein structure prediction. Implications for the biologist. Biochimie 79: 681-686.

49. Ginalski K, Elofsson A, Fischer D, Rychlewski L (2003) 3D-Jury: a simple approach to improve protein structure predictions. Bioinformatics 19: 10151018.

50. Sanchez R, Sali A (2000) Comparative protein structure modeling. Introduction and practical examples with modeller. Methods Mol Biol 143: 97-129.

51. Henderson KA, Streltsov VA, Coley AM, Dolezal O, Hudson PJ, et al. (2007) Structure of an IgNAR-AMAl complex: targeting a conserved hydrophobic cleft broadens malarial strain recognition. Structure 15: 1452-1466.

52. Reeves JD, Gallo SA, Ahmad N, Miamidian JL, Harvey PE, et al. (2002) Sensitivity of HIV-1 to entry inhibitors correlates with envelope/coreceptor affinity, receptor density, and fusion kinetics. Proc Natl Acad Sci U S A 99: 16249-16254

53. Henderson HI, Hope TJ (2006) The temperature arrested intermediate of viruscell fusion is a functional step in HIV infection. Virol J 3: 36.

54. Jacobs A, Quraishi O, Huang X, Bousquet-Gagnon N, Nault G, et al. (2007) A covalent inhibitor targeting an intermediate conformation of the fusogenic subunit of the HIV-1 envelope complex. J Biol Chem 282: 32406-32413.

55. Melikyan GB, Markosyan RM, Hemmati H, Delmedico MK, Lambert DM, et al. (2000) Evidence that the transition of HIV-1 gp41 into a six-helix bundle, not the bundle configuration, induces membrane fusion. J Cell Biol 151: 413-423.

56. Zhu P, Liu J, Bess J Jr., Chertova E, Lifson JD, et al. (2006) Distribution and three-dimensional structure of AIDS virus envelope spikes. Nature 441: $847-$ 852.

57. Chan DC, Fass D, Berger JM, Kim PS (1997) Core structure of gp41 from the HIV envelope glycoprotein. Cell 89: 263-273.

58. Weissenhorn W, Dessen A, Harrison SC, Skehel JJ, Wiley DC (1997) Atomic structure of the ectodomain from HIV-1 gp41. Nature 387: 426-430. 
59. Wild CT, Shugars DC, Greenwell TK, McDanal CB, Matthews TJ (1994) Peptides corresponding to a predictive alpha-helical domain of human immunodeficiency virus type $1 \mathrm{gp} 41$ are potent inhibitors of virus infection. Proc Natl Acad Sci U S A 91: 9770-9774.

60. Jiang S, Lin K, Strick N, Neurath AR (1993) HIV-1 inhibition by a peptide. Nature 365: 113.

61. Lu M, Kim PS (1997) A trimeric structural subdomain of the HIV-1 transmembrane glycoprotein. J Biomol Struct Dyn 15: 465-471.

62. Jacobs A, Sen J, Rong L, Caffrey M (2005) Alanine scanning mutants of the HIV gp41 loop. J Biol Chem 280: 27284-27288.

63. Kim S, Pang HB, Kay MS (2008) Peptide mimic of the HIV envelope gp120gp41 interface. J Mol Biol 376: 786-797.

64. Caffrey M (2001) Model for the structure of the HIV gp4l ectodomain: insight into the intermolecular interactions of the gp41 loop. Biochim Biophys Acta 1536: $116-122$.

65. Fenouillet E, Barbouche R, Jones IM (2007) Cell entry by enveloped viruses: redox considerations for HIV and SARS-coronavirus. Antioxid Redox Signal 9: 1009-1034.

66. Barbouche R, Lortat-Jacob H, Jones IM, Fenouillet E (2005) Glycosaminoglycans and protein disulfide isomerase-mediated reduction of HIV Env. Mol Pharmacol 67: 1111-1118.

67. Mao Y, Wang L, Gu C, Herschhorn A, Xiang SH, et al. (2012) Subunit organization of the membrane-bound HIV-1 envelope glycoprotein trimer. Nat Struct Mol Biol 19: 893-899.

68. Labrosse B, Treboute C, Alizon M (2000) Sensitivity to a nonpeptidic compound (RPR103611) blocking human immunodeficiency virus type 1 Env-mediated fusion depends on sequence and accessibility of the gp41 loop region. J Virol 74: 2142-2150.

69. Murray EJ, Leaman DP, Pawa N, Perkins H, Pickford C, et al. (2010) A lowmolecular-weight entry inhibitor of both. J Virol 84: 7288-7299.
70. Earl PL, Broder CC, Doms RW, Moss B (1997) Epitope map of human immunodeficiency virus type $1 \mathrm{gp} 41$ derived from 47 monoclonal antibodies produced by immunization with oligomeric envelope protein. J Virol 71: 2674 2684

71. Xu JY, Gorny MK, Palker T, Karwowska S, Zolla-Pazner S (1991) Epitope mapping of two immunodominant domains of gp41, the transmembrane protein of human immunodeficiency virus type 1, using ten human monoclonal antibodies. J Virol 65: 4832-4838.

72. Binley JM, Sanders RW, Clas B, Schuelke N, Master A, et al. (2000) A recombinant human immunodeficiency virus type 1 envelope glycoprotein complex stabilized by an intermolecular disulfide bond between the gp120 and gp41 subunits is an antigenic mimic of the trimeric virion-associated structure. J Virol 74: 627-643.

73. Helseth E, Olshevsky U, Furman C, Sodroski J (1991) Human immunodeficiency virus type 1 gp120 envelope glycoprotein regions important for association with the gp41 transmembrane glycoprotein. J Virol 65: 2119-2123.

74. Wang J, Sen J, Rong L, Caffrey M (2008) Role of the HIV gp120 conserved domain 1 in processing and viral entry. J Biol Chem 283: 32644-32649.

75. Pancera M, Majeed S, Ban YE, Chen L, Huang CC, et al. (2010) Structure of HIV-1 gp120 with gp41-interactive region reveals layered envelope architecture and basis of conformational mobility. Proc Natl Acad Sci U S A 107: 11661171.

76. Herrera E, Tenckhoff S, Gomara MJ, Galatola R, Bleda MJ, et al. (2010) Effect of synthetic peptides belonging to E2 envelope protein of $\mathrm{GB}$ virus $\mathrm{C}$ on human immunodeficiency virus type 1 infection. J Med Chem 53: 6054-6063.

77. Baba M, Nishimura O, Kanzaki N, Okamoto M, Sawada H, et al. (1999) A small-molecule, nonpeptide CCR 5 antagonist with highly potent and selective anti-HIV-1 activity. Proc Natl Acad Sci U S A 96: 5698-5703. 